


\section{Digitized by the Internet Archive in 2007 with funding from Microsoft Corporation}





THE INDUSTRIAL AND COMMERCIAL INFLUENCE OF THE ENGLISH PATENT SYSTEM 

$R 2542$ in

\title{
THE INDUSTRIAL AND
}

COMMERCIAL INFLUENCE OF THE ENGLISH PATENT SYSTEM

\author{
By A. F! RAVENSHEAR \\ Bachelor of ScIence, LoNdoN \\ Whitworth Scholar
}

"... so they be not ... mischievous to the State, by ... hurt of trade, or otherwise inconvenient."

T. FISHER UN W IN LONDON : ADELPHI TERRACE LEIPSIC : INSELSTRASSE 20 1908 
(All rights reserved.) 


\section{PREFACE}

WHILE many works deal fully with patents in their legal aspect, and to a less extent with their history, there is none, so far as the writer is aware, in which they have been treated with equal fulness on the economic side. At the same time the references to patents in treatises on Economics are of the scantiest.

This little book is offered as a contribution towards making good the deficiency. Since. the higher claims of the inventor are not referable solely to economic considerations, it is unavoidable that in a purely economic discussion of patents the interests of the inventor should appear to some extent to be subordinated to those of the manufacturer. This is entirely due to the fact that Economics takes only a partial view of the subject; and the writer desires especially to emphasise this 
point in order to guard against any misconception as to his attitude towards the inventor.

It is hoped that the book may be found suggestive not only to those whose primary concern is with patents, but also to students of Economics and to all those to whom the tracing out of the conditions of the well-being and advancement of the manufacturing industries of the country appears worthy of attention.

A. F. R.

October, 1908. 


\section{CONTENTS}

\section{CHAPTER I}

THE SUBJECT OF INQUIRY: THE ECONOMIC UTILIT OF THE PATENT SYSTEM

\section{CHAPTER II}

THE ECONOMIC FUNCTION OF INVENTION

Determined in general terms-Invention and unemployment-Invention and rise and fall of tradeInvention and international commerce.

\section{CHAPTER III}

EVIDENCE OF THE OPERATION OF PATENTS

Invention in the agricultural arts-Features peculiar to trade of Holland-Originative invention dependent on patents.

\section{CHAPTER IV}

THE OPERATION OF PATENTS MORE CLOSELY CONSIDERED

Intensive and originative invention distinguishedIntensive invention reviewed-Originative invention reviewed-Restatement of primary effect of patents. 


\section{CHAPTER V}

ANTI-INDUSTRIAL FEATURES OF THE PATENT SYSTEM

Obstructive use of patents-Oppressive exercise of patent rights-Predaceous and bluffing uses of patents -Bismarck's indictment of the Patent System.

\section{CHAPTER VI}

EVIDENCE AFFORDED BY LONG-LIVED PATENTS

\section{CHAPTER VII}

PATENT SYSTEMS OF ENGLAND, GERMANY, AND AMERICA COMPARED

Efficiency with regard to originative inventionAttitude towards intensive invention-The position of the foreigner-Comparative values of patent grants in England and Germany.

\section{APPENDIX}

STATISTICS USED IN CHAPTER III.

INDEX . 


\section{CHAPTER I}

THE SUBJECT OF INQUIRY : THE ECONOMIC UTILITY of THE PATENT SYSTEM

NE country alone among the commercial and industrialised nations of the world grants no patents for inventions. By an Act of the Legislature in the year 1869, the patent system till then existing in Holland was entirely abolished. That there is no other exception among civilised States to the practice of vesting inventors with some of the rights of property in their ideas shows how strong the case in favour of the inventor is generally thought to be. On the other hand, the fact that a people with so honourable a record as the Dutch in science and invention should have taken this step is clear proof that the principle on which legal property in inventions is founded is not so entirely axiomatic as some authorities have conceived. 
Sometimes the granting of monopolies to inventors is regarded as a simple act of justice. John Stuart Mill says: "It would be gross immorality in the law to set everybody free to use a person's work without his consent and without giving him an equivalent." More often patents are justified on grounds of expediency. Mr. Lloyd George stated in the House of Commons in the debate on the Patents Bill of 1907: "The object of the Patent Laws is to reward ingenuity, and by so doing to encourage invention and to promote British industry." It has, however, in the past been seriously questioned whether invention would not progress equally well without patents, and whether upon the whole patents are not more detrimental to the progress of industry than advantageous. At the time when the patent system in Holland was abolished there occurred a parallel movement of opinion in this country adverse to patents. The patent system was attacked on the ground that it was economically disadvantageous, but the defenders did not attempt to disprove this by showing a balance of advantage; they rested the defence of the system mainly upon abstract ideas of 
property and on the claims of justice. The position at the present day is tersely summarised by Dr. Martin thus*: "The statesman, while ready to allow natural justice full weight, may be more inclined to expediency as his basis of action, while the theoretic reformer would perhaps place natural justice in the front rank. The economic grounds urged for the maintenance of a patent system may not of themselves silence controversy; but when conjoined with the feeling that the inventor is deserving of recompense they find a powerful and decisive support."

A sufficient period has elapsed since the total disappearance of patents from Holland to enable some of the consequences to become apparent. In view of this, and as recent discussions in connexion with the amendment of our Patent Law have once more brought into prominence the economic aspect of the operation of patents, it has appeared to the writer that it might be of interest to examine the patent system anew, in order to ascertain how far the system as a whole can be justified

* "The English Patent System," by William Martin (1904), p. 25. 
on economic grounds alone; how far its assumed economic advantage can be verified by observation; and to ascertain, as far as possible, the nature and extent of its economic effects.

In pursuance of this design an attempt is made to show the economic function of invention, understood broadly, apart from patents ; to show its influence in the production of employment and unemployment; its bearing on the periodic rise and fall of trade; and the importance of its office in relation to the commerce of the world. Some evidence of the nature of the aggregate effect produced by patents is next adduced. It will be seen that while improvement of the agricultural arts has proceeded to a great extent independently of patent protection, the manufacturing trades in Holland have been relatively less favourably circumstanced than those in the neighbouring countries. It is shown that the conclusion can scarcely be avoided that, while certain kinds of invention advance as freely without the aid of monopolies as with such aid, other kinds of invention require the protection of patents in order to reach their full development. This is more 
especially true of the pioneer and creative class of inventions. Abuses of the patent monopoly are then dealt with in the light of the preceding conclusions ; Bismarck's indictment of the patent system is also reviewed in the same light; and the general conclusions are tested by reference to a number of patents which have established their claim to consideration by surviving the full term of fourteen years. The work concludes with a brief comparison of some of the economic features of the patent systems of the United Kingdom, Germany, and the United States of America. 


\section{CHAPTER II}

THE ECONOMIC FUNCTION OF INVENTION

ПHE economic operation of patents must 1 be distinguished from the economic function of invention. Invention is obviously to some extent independent of patents; while patents bring in their train certain secondary consequences which have to be separately investigated. So far, however, as the patent system fulfils its purpose, it promotes invention, and thereby intensifies those effects which are attributable to invention. The determination of the office fulfilled by invention in the industrial and commercial world is therefore the first step in an examination of the economic effects which are consequent upon the grant of patents.

Invention, or the exercise of originality, is not confined, in its application to commerce and industry, to the introduction of new 
technical processes and results. Originality is the chief component of enterprise.

Economically the term "invention" ought to include any advantageous departure from what is customary in the arts or in commerce, whether or not the novelty is of such a nature that its exclusive use could be secured to the introducer by means of a patent. It must also be remembered that it is the use and exploitation of inventions which produce economic effects, not their mere existence as unnoticed and unutilised proposals. The term thus understood covers all extensions in the application of that directive ability, the important office of which is very effectively and clearly set forth by Mr. Mallock in his "Critical Examination of Socialism." It denotes the fruit of the operation of originality in the conception of new commercial enterprise and of improved commercial methods as well as invention in the industrial arts. Both of these are essential to economic progress, and each contributes to the effectiveness of labour; the one directly by improving means and appliances, the other chiefly by organisation. The effects of these two classes of invention are so similar that in 
the consideration of the present subject they cannot be separated. It will be seen, however, that an examination of the subject leads to the recognition of a further distinction between one kind of invention and another based upon differences in their economic action, but the line of division crosses both commercial and industrial invention. These two kinds are pioneer or creative invention, whether industrial or commercial, which may conveniently be termed "originative," and the mere improvement or cheapening of existing methods, which in the following pages is called "intensive." We proceed first to ascertain the function of invention in relation to the community as a whole; and, incidentally, light will be thrown upon the effects produced upon different classes of the community.

What are the influences which tend to bring about industrial development? At what point do such influences begin to act? and how do they operate? To these questions economic science gives the answer that industrial development originates in an increase in the productiveness of labour. Among the means whereby the productiveness of 


\section{THE ECONOMIC FUNCTION OF INVENTION 17}

labour is increased, it enumerates some connected with the education and character of the workman, some connected with security and good government, some connected with the inducements to the accumulation of capital and the stimulation of enterprise. In addition to these, it also specifies others that more especially concern the present subject, namely, the greater economy of operations carried out on a large scale, the subdivision of labour, the use of improved processes, and the substitution of machine for hand work. It will be recognised that the causes included in this last group originate principally in invention.

Briefly, then, one of the chief causes of industrial development is invention. An increase of productive power due to invention opens the way to the growth of capital, and enables the community to support a larger industrial population. But the answer given in such general terms omits all reference to the mechanism of trade and, however correct, is far from complete. We wish to know how and by what steps inventions relating to the work of a part of the community react upon trade, and operate to increase the industrial 
activity and purchasing power of the whole community. Not only does the answer above lack this detail, but it is also incomplete in another respect. It is not all invention that subserves merely a reduction in the cost of known commodities. A part is devoted to the satisfaction of new wants and the supply of new products. But wants without means do not form an effective demand. We wish to trace out how invention can generate an effective demand; in other words, how it can extend existing markets and create new ones.

The economic answer, still in general terms, is that a new supply of commodities is an effective demand for others; and therefore the effective beginning of industrial development is the origination of new commodities. The origination of a new supply of commodities presupposes, however, the existence of uninvested capital and unemployed labour. If the question be pressed, How comes it that there are always such supplies of capital and labour? we arrive at the answer that this is due to antecedent improvements in the productiveness of labour; in which again invention has played the chief part. We are thus led to the recognition of two classes of 
invention mutually related: the first operating to reduce the cost of existing commodities, and thereby opening the way to the introduction of new commodities furnished by the second.

A simple imaginary case will enable the argument to be shortly but more clearly stated. Let us suppose we are face to face with a self-contained community like Tibet, economically stationary, drawing food supplies from the pasturage and tillage of snowbounded valleys, governed by a priestly body obstinately resisting all intercourse with foreigners, possessing little or no currency, and supporting village craftsmen who have advanced beyond a rudimentary stage in the arocations of the miner, the metal-worker, the potter, the tanner, and the builder. Imagine the consequences of the discovery and adoption of some improvement in their processes of agriculture. Their granaries fill, and unless some other change occurs they become indolent or wasteful. On the other hand, suppose that, without any enlargement of their food supplies, the ingenuity of their craftsmen offers them a new product of native skill. They must either go without the new 
article or submit to a curtailment of their supplies in some other direction. But if the offer of the new article supervenes on an enlargement of their food production, a balance between consumption and production may again be attained by the entry into the ranks of the craftsmen of some of the oncoming youth of the country no longer needed on the farms or pastures. If, on the other hand, the increase; of productiveness occurred in one of their crafts, there would equally be presented to the craftsmen the opportunity to practise their skill in the new direction.

Let us now turn to a highly developed industrial and commercial community with practically no unutilised natural resources. What differences shall we find in regard to these two movements? The differences in detail will be great, but beyond the fact that, trade and manufactures being more completely organised and less restricted by custom, we may expect such changes to occur on a larger scale and with greater facility, there appears no reason to doubt that the essential characters of the movements will be essentially the same. In this country the improvement of industrial processes is so continuous 
and widespread, and the introduction of new articles of manufacture so frequent, that there can be no question as to the reality of the action of these two classes of invention, or that in the aggregate they produce extensive economic consequences. We are thus in a position to give a more detailed yet summary answer to the questions: What are the influences which tend to bring about industrial development? At what point do they begin to act? and how do they operate?

Wherever production is cheapened, there we are at the growing-point of industrial development. The manner in which the change operates is to increase the profits of the manufacturers who adopt the improved processes, and to set free a portion of the resources of the consumers of the cheapened article. Markets are thus created for new articles of manufacture, and capital formed in readiness for new productions. At the same time the immediate effect of cheapened production is a tendency to diminish total activity and the area of employment. This tendency may be counteracted by the invention of new products; while the general introduction of new products is itself depen- 
dent on the preparation of capital and labour which has ensued upon the previous cheapening of products already in use. Briefly, the function of intensive invention is to prepare the way for the adoption of originative invention, and of originative invention to counteract the unemployment and other disturbances generated by intensive invention. The distinction between the action of intensive and originative invention being recognised, the significance of this condensed statement of the economic function of invention will gain in completeness by being considered more particularly in relation to employment and unemployment of the wage-earner, in relation to the periodic rise and fall of trade, and in relation to international commerce.

\section{Invention and Unemployment.}

While the particular works or town where an improved method comes into use may be rapidly extended to cope with expanding trade, yet, in the places where the older processes still persist, the trade of the manufacturer and employment of the wage-earner may suffer a more than proportional shrinkage. 
THE ECONOMIC FUNCTION OF INVENTION 23

It is a matter of common observation that when a cheapening of any article occurs, the demand increases, and ultimately the consumption may become so much enlarged as more than to make up for the reduction in price, the total value of the produce being greater than before, and this might be thought to negative the conclusion set out above. It might be supposed that the cheapening alone is an influence which tends to an increase of industrial activity and an enlargement of the area of employment. But closer consideration shows this conclusion to be tenable only on condition of not inquiring into the circumstances attending the creation of fresh markets or the expansion of existing markets. If at any time a balance exists between the expenditure of consumers and the supplies of commodities, and the balance were disturbed by a cheapening of any one of the articles of consumption, it might be restored again by an increase of consumption of that article exactly equivalent to its fall in price. The consumption could not be increased beyond that point unless, by the operation of other causes, the consumers found new resources or had existing resources 
set free. Resources might be set free by the cheapening of other commodities, but the same considerations would still apply to the total body of cheapened articles. It appears, then, that cheapening, although it may alter the division of the expenditure of consumers, cannot alone increase it. The necessary condition of the observed increase is the invention and introduction of new manufactures, which give scope for the application of the resources and activities set free by the increased productiveness of labour to which the relative cheapening of commodities is due; and it is to these that the ultimate more than proportional increase of trade brought about by cheapening which commonly occurs is rightly to be attributed.

The joint operation of improved processes and creative invention when they work harmoniously is to enhance the material wellbeing of the entire community as regards the provision of commodities. They work harmoniously when they are so co-ordinated that the institution of new manufactures is sufficiently rapid and widespread to check the spread of unemployment due to intensive invention-that is, when the invention of new 
arts and new products treads close on the heels of improvements in the existing arts. When the improvement of processes outstrips the provision of new manufactures, the direct beneficial action may be disguised by much inconvenience. The advantage which the consumer derives from the cheapening of wares is not shared by the displaced wageearners, or those manufacturers and traders who, not being in the van, suffer from the competition of their more advanced rivals.

It is true that those manufacturers and traders who find themselves at a disadvantage owing to improvements introduced by their competitors may be stimulated to the introduction of still further improvements, and thereby recover their relative position. But in the absence of counteracting originative invention this cannot remedy, but tends to intensify, the prejudicial consequences to the wage-earner.

The result is similar when the competition takes the form of the importation of cheaper commodities as a result of intensive invention abroad. This may be combated, so far as the manufacturer and trader are concerned, by greater activity in the introduction of improve- 
ments on their side; but as in the case of home competition, except in so far as it is counteracted, the effect on the wage-earner is the same.

It would appear, then, that unemployment is not generated by invention simply; but is due to intensive invention outstripping originative invention. And an important inquiry, to be undertaken subsequently, will be to determine the influence of the patent system on invention of these two kinds.

\section{Invention and the Rise and Fall of Trade.}

If these conclusions are sound, it would appear that the progress of one kind of invention rather than another is one of the primary economic forces which contribute to the production of periods of depressed trade. Such a view demands more support than can be derived merely from abstract and theoretical reasoning; but the writer believes that this possibility is one that in our own industrial history has been realised on several occasions, and that the characteristics of the rise and fall of trade during the past century furnish the requisite confirmation. In order to pick 
out these characteristics it is first, however, necessary to pursue the subject somewhat further, and to sketch some of the consequences that might be expected to ensue upon a continued and widespread lowering of cost of production unaccompanied by a countervailing invention of new manufactures.

When an improvement occurs in any one manufacture the effect is to give an advantage to those manufacturers who first adopt it. Their trade increases, and with extension of their operations further economies ensue. The smaller and less enterprising makers lose business, and continue to trade under inconvenience and reduced profits. Subsequent lowering of prices increases their difficulties, and their trade appears to be suffering from the effects of over-production. If similar movements in many trades are proceeding concurrently the effect is to colour trade in the aggregate. Complaint begins to be raised on many sides of the lowness of profits owing to excessive cheapness; the evil is attributed to general over-production; unemployment is seen in many quarters. The total volume of trade may, nevertheless, be as great as or greater than ever, the falling off being appa- 
rently in values. At the same time there is to be expected enlargements and amalgamations of works due to the concentration of trade in fewer hands. It must be remembered that the spectacle of wage-earners without work, the failure of traders and manufacturers, when seen in many localities, coupled with complaints of the severity of competition and low wages of those who are suffering from the consequences of industrial change, is calculated to impress itself upon the imagination and to tinge with gloom the whole outlook. The advanced and enterprising section of the industrial world whose trade increases notwithstanding the lowering of prices, to whose action indeed the cheapening of commodities is due, have no cause to join in the general outcry; neither have they any inducement to call attention to their own prosperity as a setoff against the inconveniences felt by others. And if they did it is unlikely that those who felt the pinch would thereby be convinced. Altogether we are led to picture a state of affairs bearing considerable resemblance to that which prevailed during the long period of depressed trade, especially that portion of it extending from 1873 to 1882 , that followed 
THE ECONOMIC FUNCTION OF INVENTION 29

the years of expanding trade, culminating in the year 1873 .

That period was characterised by an enormous increase in the number of joint-stock companies and growth in size of industrial concerns. It was said that the private trader was being squeezed out of existence. It was said that trade was being ruined by the unremunerative cheapness of commodities. The apparent injury to trade was attributed by some to excessive competition; by others to "general over-production." At the same time it was a frequent subject of remark that the trade returns, although they might show a falling 'off in values, did not indicate a corresponding shrinkage in the volume. Failures were more than usually numerous, and the indications of widespread unemployment were more than usually prominent. Yet the general comfort and standard of living continued to improve, and from this it may be inferred that the unfavourable incidents which loomed so large in the public mind were, nevertheless, partial in their operation upon the community although widely distributed as regards locality and trades. Many of the signs of depressed trade, in fact, agree with those which can be 
shown to be likely to ensue upon originative invention being overtaken by intensive invention, or, in other words, by long-continued and excessive cheapening of the processes of production.

It is not suggested that the varying trend of invention is the chief factor in the rise and fall of trade, but the above considerations would appear to show that this cause is at any rate a very influential contributory to those traits which are commonly regarded as signs of depression.

Invention and International Commerce.

In regard to the economic function of invention, it is lastly worthy of note that the two classes of invention tend to establish both those conditions which have been recognised by economists as the source of the advantage derivable from international trade. These comprise a difference in relative costs of production of commodities which are obtainable in each of two countries, and the existence of certain commodities which can be obtained only in one or the other. Originative invention introduces new commodities, and intensive 
THE ECONOMIC FONCTION OF INVENTION 31

invention alters relative costs of production. The only feature that distinguishes this cause of foreign trade from those natural advantages of climate and resources which play so important a part in the production of the world's commerce is the want of permanence in its localisation. Our own history contains many instances of the transplanting of industries. But it is easy to over-estimate the possibility of transferring industries from one place to another, or of setting them up in new localities.

Industries usually remain rooted in particular places for long periods, like the steel trade at Sheffield, the textile industry in Lancashire, and the hardware trade at Birmingham. This is largely due to the mutual dependence of trades, and, in the highest degree, to the industrial community in these places forming a natural forcingground for the propagation of special knowledge and skill.* These advantages by themselves might not suffice to maintain the lead which these centres have so long enjoyed over other manufacturing centres. The influence

* Cf. "The Sheffeld Steel Trades," by Dr. A. Shadwell, in The Times Engineering Supplement, May 6 and 27, 1908. 
of such advantages may be compared to that of a favourable soil in promoting the germination of invention, the seed of industry. So long as the manufacturers in such districts are enterprising enough, as they have been in the past, to be ready to give new ideas a trial, the tendency will be for inventions to be brought to the place where the industry is practised rather than for the industry to migrate. In this way invention tends to perpetuate and to emphasise the distinctive character of manufacturing districts, and to assimilate those conditions which at first sight ha:e the appearance of being artificial to those features of nature which are beyond control. The trading advantages of an old-established and progressive manufacturing country tend therefore to increase rather than to diminish if the action of invention is allowed to take place freely and without artificial hindrance.

Although an old and progressive manufacturing country presents features calculated in this way to give stability to any superiority it may possess over newer manufacturing centres, yet the localisation of manufactures is not altogether beyond control or modification. Hindrances to the free development of 
THE ECONOMIC FUNCTION OF INVENTION 33

invention may be created; and just as invention utilised in this country gives rise to profitable foreign trade, so the opportunity and inducement for such trade may, through the operation of artificial restraints, be destroyed in certain directions by the diversion of invention to places abroad. In that way invention which might otherwise enlarge the inequalities in which foreign trade originates, may tend to equalise the industrial conditions in distant places, and thus to diminish the opportunities for international trade. In this connexion we shall hope to show later the importance of a good patent system.

Seeing how dependent this country is upon imports for so large a part of its food supply, the function of invention in the promotion of foreign trade is perhaps of more importance to the United Kingdom than to any other country in the world. It may, indeed, be said that to a great extent the people of this country depend for their subsistence upon invention; and that the unfettered adoption of every advance and improvement that the concentration of industrial skill and knowledge in this country renders possible is essential to their well-being. 


\section{CHAPTER III}

EVIDENCES OF THE OPERATION OF PATENTS

T $\mathrm{N}$ the preceding discussion the nature of 1 the economic function of invention understood in its widest sense has been sketched, the term having been used to denote all improvements in both the commercial and industrial fields. As, however, this inquiry is intended to subserve more particularly an investigation of the operation of patents for inventions, the more general aspects of invention may now be left on one side and attention fixed more closely upon the leading features of invention in the industrial arts.

The diverse effects of originative invention and intensive invention have been broadly indicated. In order to ascertain the economic operation of the patent system, it is proposed now to examine the influence of the granting of patents upon these two classes of invention. 
Would the inventions be forthcoming in the absence of the inducements which the patent system holds out to inventors? Is the reward obtainable by an effective use of the monopoly an essential condition of the exercise of his faculty by the inventor and of the exploitation of the invention by the capitalist? And do these inducements operate on both classes of invention alike?

We should be able to determine what the effect of the patent system is upon industry if we could determine what would be the state of affairs if no patents were granted, by making a comparison between that state of affairs and existing conditions. It might be expected that here we must necessarily enter into a hypothetical discussion. Fortunately, this is not the case. In the Netherlands we have an example of an old manufacturing country, resembling our own in many respects and pursuing a policy of Free Trade, in which no patents have been granted since the year 1869. And in agriculture we have a productive industry to which, over a large field which affords scope for invention, the encouragement afforded to the manufacturer by patents does not extend. These furnish us with the means 
of making the desired comparison, and the result to which we are led is, broadly, that while the progress of intensive invention is to a great extent independent of patents, originative invention reaches its full development only under a patent system.

\section{Invention in the Agricultural Arts.}

How it happens that in regard to the work of the farmer discovery and ingenuity have to go without the reward which is accorded them in other industry is easier to explain than to justify. It has been well said that it is probably an accident of our history. ${ }^{*}$ At the time when the famous exception in the Statute of Monopolies was framed, crafts and mysteries existed abroad which might be established in this country if those who practised them could be induced to settle here under the protection of a monopoly. But it was not till a hundred years later that the mere improvement of an existing industry came to be regarded as falling within the Statute. At the time of James

* "The English Patent System," by William Martin (1904), p. 40. See also in this some interesting remarks on "Unpatentable Projects, Enterprises and Ideas." 
farming and pasturage were the established industries of the country, and these did not seem to stand in need of the encouragement which it was thought fit to extend to new manufactures. Perhaps if the legislators of 1624 had foreseen the possibility of invention in the agricultural arts as they did in the manufacturing arts, the foundation of the existing patent system might have been laid more broadly.

In case there might be thought to be something fanciful in thus comparing advance in the processes of husbandry with invention in manufactures, let it be remembered that in each case there is the exercise of ingenuity, or the application of scientific principle, issuing in a practical result and increasing the effectiveness or productiveness of labour. The craftsman is as dependent upon the operations of nature as the farmer. It would seemingly be equally possible to encourage and protect the improver of agricultural method, or the introducer of an improved variety of domestic animal, or of a giant potato, by a limited monopoly in the exercise of his art as in the case of the mechanical inventor. The analogy appears to hold throughout, and it seems, 
therefore, perfectly fair to utilise the progress of agriculture as a gauge by which to judge what in the absence of patents would be the state of the manufacturing industries.

Whatever the reason for the difference in treatment of manufactures and agriculture, the significant fact in relation to the present inquiry is the steady and continuous improvement in husbandry which the ingenuity of breeders and agriculturists have realised in those regions to which the protection of patents does not extend. The list of improved breeds of domestic animals which have been obtained by the ingenious exercise of crossing and selection is a long one. Equally numerous is the variety of improved cereals and other vegetable products which have been obtained by like means. Garton's system of plant breeding, which is dependent on the practical application of the discovery of a method of breaking down the apparent infertility of artificially formed hybrids, is a noteworthy example of invention in agriculture. The discovery of the causes of obscure plant diseases has led to practical methods of combating them. The adaptation of methods of cultivation suitable to particular soils and the introduction of im- 
proved rotations have, like all these advances, proceeded side by side with those improvements which, involving the employment of manufactured products-such as artificial fertilisers and farming machinery-have been favoured by the grant of patents.

That the agricultural and breeding industries of this country have reached a pre-eminence comparable to that of its manufactures is well illustrated by the following extract from a recent work entitled "The Business Side of Agriculture" * -

"Agricultural statistics show that a greater number of bushels of wheat are grown to the acre in the United Kingdom than in any other country in the world, except perhaps Belgium. Large quantities of seeds are yearly exported from these islands to sow in foreign countries, and it is to this country that breeders of cattle come to buy the stock that they want to improve their own herds." And again in the same work: "Merchants send a considerable quantity [of seed corn] abroad, where the great productivity of English wheat, and its cleanness from rubbish of all kinds, including

* "The Business Side of Agriculture," by Arthur G. L. Roberts (1904), pp. 4, 18. 
the seeds of weeds, are naturally highly valued."

A similar conclusion is suggested in the paper read by Professor James Wilson at the Dublin Meeting of the British Association. In this paper it is shown that in the last two hundred years the productivity of English arabie land, upon the whole, bas increased from 8 to 30 bushels per acre, and of pasturage from 80 to 270 gallons of milk per acre.

There would, in fact, appear to be good ground for concluding that the introduction of improvements in method and the applications of scientific principle have been scarcely less effective in that region of agriculture which falls outside the scope of patents than on the other side. As invention has proceeded in husbandry without patents to an extent comparable to the progress in other industries, it is safe to infer that the advancement of manufactures is also to some extent independent of patents. It would, however, be hasty to conclude that industrial development is entirely unaffected by this form of encouragement, and a comparison of the commercial development of Holland with that of other manufacturing 
countries shows, indeed, that the contrary is the case.

Features Peculiar to the Trade of Holland.

The materials for making this comparison exist in official returns going far enough back to enable it to be commenced just after the last of the patents granted in Holland must have expired. The comparison is based on the export trade. It would, no doubt, be more satisfactory, if the information could be obtained, to compare the investment of capital in manufactures in Holland before and after the cessation of the grant of patents. This information, however, is unobtainable, so far as the writer is aware. Failing evidence of this kind, the next best is that furnished by foreign trade. In this connexion, reference may be made to the especially close relation between invention and foreign trade pointed out in the preceding chapter.

While the export trade of France, Germany, Switzerland, Italy, and the United States show a relative increase in the export of manufactured goods as compared with other products, the exports of Holland show a con- 
trary movement. The comparison extends over the twenty-one years from 1884 to 1904 . Holland, in common with the five other countries named, has during that period enjoyed an expanding trade; but, among those countries whose total trade is increasing, it is the only one whose exports show a diminishing proportion of manufactures. While in other commercially active and manufacturing countries the export of food and raw materials increases more slowly than that of manufactured goods, the export of manufactured products from the one country which grants no patents for inventions increases more slowly than that of non-manufactured articles.

The figures in the subjoined Table I. exhibit the basis of these statements. They are taken from the Statistical Abstracts issued by the Board of Trade.

While the proportion of manufactures to total exports has increased in the case of Germany from 62.8 to 65.9 per cent., of France from $52 \cdot 3$ to $57 \cdot 0$ per cent., of Switzerland from 71.2 to 75.5 per cent., of Italy from 43.3 to 60.1 per cent., and of the United States from 18.6 to 36.4 per cent., the proportion in the case of Holland has fallen from 





$27 \cdot 2$ to 17.6 per cent. In all six countries, including Holland, the exports both of manufactures and of food and raw materials during the period under review have increased. If the growth in the export of manufactured products is compared with the total export of all products the distinctive character of the change in the case of Holland is rendered still more conspicuous. The result is shown in the last two lines of Table I. While in the case of Holland the export of manufactures has increased by $52 \cdot 7$ per cent., the total exports have increased by 136 per cent. In the case of all the other countries in the Table the proportion is the other way, the export of manufactures having increased at a relatively greater rate than the total exports of those countries.

In the returns for Belgium and Russia for the whole period and for Austria-Hungary for the period 1894 to 1904 the same features occur.

The returns in the Statistical Abstracts relating to the trade of the United Kingdom are not summarised in such a way as to be directly available for comparison with the above figures over the whole period 1884 to 1904. They can, however, be directly com- 
pared from 1891 to 1906 . The total exports of home produce during that period have increased rather over 50 per cent., from $£ 247,235,000$ to $£ 375,575,000$, while the percentage of manufactured goods exported has fallen from 85 per cent. to 81.3 per cent., the amounts being $£ 211,071,000$ and $£ 305,528,000$.

During the same period the percentage of manufactured products exported from Holland fell from $21 \cdot 2$ to $17 \cdot 6$, the rate of fall being thus about four times as great as in the case of the United Kingdom.

The export trade of the several countries may also be compared in another way, which does not necessarily demand that the comparison should be made in respect to identical periods, and in this comparison the United Kingdom may be included. This method consists in taking the increase of the exports of domestic produce which has occurred during any convenient period, and determining what proportion of the increase is due to the manufactured goods exported, and what proportion is due to other produce. The larger the share of the increase which is attributable to increased export of manufactured produce in any country, the greater is the relative 


\section{TABLE II. \\ Growth of Exports of Manufactured Products Compared with Growth of Total Exports.}

Period 1884 to 1904.

\begin{tabular}{|c|c|c|c|}
\hline \multirow{3}{*}{$\begin{array}{l}\text { Switzerland } \\
\text { (1885 to } 1904)\end{array}$} & $\begin{array}{l}\text { Manufactured } \\
\text { Products. }\end{array}$ & $\begin{array}{l}\text { Total } \\
\text { Exports. }\end{array}$ & $\begin{array}{c}\text { Percentage of } \\
\text { Manufactured } \\
\text { Products. }\end{array}$ \\
\hline & $\begin{array}{c}\text { Million francs. } \\
673 \\
477\end{array}$ & $\begin{array}{c}\text { Million francs. } \\
819 \\
669\end{array}$ & \\
\hline & $\overline{196}$ & $\overline{150}$ & $130 \cdot 0$ \\
\hline \multirow[t]{2}{*}{ Italy } & $\begin{array}{c}\text { Million lire. } \\
960 \\
429\end{array}$ & $\begin{array}{c}\text { Million lire. } \\
1,597 \\
993\end{array}$ & \\
\hline & 531 & 604 & $87 \cdot 9$ \\
\hline \multirow[t]{2}{*}{ Germany } & $\begin{array}{c}\text { Million marks. } \\
3,442 \\
2,013\end{array}$ & $\begin{array}{c}\text { Million marks. } \\
5,223 \\
3,205\end{array}$ & \\
\hline & $\overline{1,429}$ & 2,018 & $78 \cdot 6$ \\
\hline \multirow{2}{*}{$\begin{array}{c}\text { United } \\
\text { Kingdom } \\
\text { (1891 to } 1906)\end{array}$} & $\begin{array}{l}\text { Million } \mathfrak{f} . \\
305 \\
211\end{array}$ & $\begin{array}{c}\text { Million } £ . \\
375 \\
247\end{array}$ & \\
\hline & $\overline{94}$ & $\overline{128}$ & $73 \cdot 4$ \\
\hline \multirow[t]{2}{*}{ France } & $\begin{array}{c}\text { Million francs. } \\
2,536 \\
1,690\end{array}$ & $\begin{array}{c}\text { Million francs. } \\
4,451 \\
3,232\end{array}$ & \\
\hline & $\overline{846}$ & $\overline{1,219}$ & $69 \cdot 4$ \\
\hline \multirow[t]{2}{*}{ United States } & $\begin{array}{c}\text { Million dollars. } \\
523 \\
136\end{array}$ & $\begin{array}{c}\text { Million dollars. } \\
1,435 \\
724\end{array}$ & \\
\hline & 387 & 711 & $54 \cdot 4$ \\
\hline \multirow[t]{2}{*}{ Holland } & $\begin{array}{c}\text { Million gulden. } \\
349 \\
228\end{array}$ & $\begin{array}{c}\text { Million gulden. } \\
1,985 \\
841\end{array}$ & \\
\hline & 121 & $\overline{1,144}$ & $10 \cdot 5$ \\
\hline
\end{tabular}


importance of the development of manufacturing industry occurring in that country to other industry which is to be inferred. This comparison is summarised in Table II. In this Table not only does Holland show the lowest proportion of all, but the step down from the next higher in the list compared with those above is remarkable. More complete statistical information is given in Part $I$. of the Appendix.

The returns on which the comparison is based include only domestic products, and exclude as far as possible re-exports and merchandise passing through the country to other destinations. In the case of Holland, however, it is known that goods in transit, especially to and from Germany, are often entered as for home consumption, and therefore appear among the exports as domestic produce. No precise correction can be made for this. Since, however, the trade in manufactured goods forms a larger and a more rapidly expanding part of the foreign trade of Germany than of Holland, the correction, whatever it might amount to, would in all probability have the effect of reducing still more the percentages showing the relative 
decline in the export of manufactured goods from Holland as compared with the export of food and raw materials. The grounds for this conclusion are explained more fully in Part II. of the Appendix.

In view of all the above considerations it appears that the development of the mechanical arts has taken place in Holland under less favourable conditions compared with those under which the agricultural and associated arts have developed than in any of the other great manufacturing nations.

This result can scarcely be attributed to the want of mineral resources, for Holland is connected with the coal and iron fields of Germany by the Rhine, and with those of Belgium by the cheapest railway system in the world. The coal and iron deposits of Belgium are, in fact, no more distant from Holland than are those of the northern and western portions of England and Wales from the south and east of England. The result cannot be attributed to failing energy and enterprise on the part of the Dutch, since the export trade of Holland shows an enormous increase in manufactured products as well as in other products. If, again, it were due to 
the policy of Free Trade pursued by the Dutch, we should expect England to occupy a position in the above comparison similar to that of Holland. If, indeed, there were any other circumstance which distinguished Holland alone from all the countries entering into the comparison the result might be otherwise explainable; but unless some feature can be found, other than the absence of a patent system, in which such diversely situated countries as Germany, France, Italy, Switzerland, the United States, Belgium, and Great Britain resemble each other while differing from Holland, the conclusion seems unavoidable that the change which has been taking place over a long period in Holland is due to the absence of a patent system.*

Originative Invention Dependent on Patents.

The conclusion drawn from an examination of the export trade of Holland appears at first sight to be totally at variance with that drawn from a consideration of the development of agriculture. While the course of trade in Holland appears to have been profoundly modified by the suppression of

* The returns of Dutch trade, 1861-73, under the patent régime are confirmatory (see Appendix, part iii.). 
patents, the application of scientific principle and the introduction of improvements in method appear to have proceeded as freely in that region of agriculture not touched by patents as in those parts to which patents apply. There is, however, an important feature in the trade of Holland which enables these apparently discordant results to be harmonised. In the twenty years under review, the exports of manufactured goods from Holland increased by over 50 per cent. This shows that the manufacturers of Holland have as regards cheapness of production been able to compete successfully in the markets of the world with other manufacturing countries, and that the relative falling off in manufactures has not been due to the non-use of intensive invention. The two results are brought into agreement by the assumption that the advancement of a large part of intensive invention is independent of patents, while the adoption of originative invention to the greatest possible extent is essentially dependent upon them. The assumed indifference of intensive invention to patents, it is true, applies strictly only to that part of intensive invention that does not depend upon the 
origination of new machinery, but which can be effected by the improvement and adaptation of existing machinery to new purposes. But, on the other hand, it may be surmised that in this respect Holland derives some benefit from the patent systems of her neighbours. She has the opportunity of intensive development of her industries by the use of machinery originated elsewhere; her position, in fact, is somewhat like that of the man who is not troubled by mice because his neighbours keep cats.

The supposition of a slower development of originative invention in Holland, owing to the absence of the encouragement afforded by patents, would explain the progressive change in the character of the foreign trade of the Dutch; while the comparative indifference of intensive invention to patents would agree with the continued expansion of that trade in amount, and would equally agree with the independence of patents of agricultural development.

This explanation is confirmed by a closer inspection of the trade relations of the two classes of invention; such an inspection enables us to see why the one class should 
be indifferent to patents and the other not so. It will be remembered that intensive invention is that which cheapens products which are already articles of trade. A manufacturer with an established business is under the strongest inducement to adopt any means available for cheapening the production of such articles. His market being assured, the adoption of such means is not only calculated to bring him additional profit, but the risk of not finding a market which attaches to new products is absent. The cheapening of production is, in fact, the most powerful instrument of competition he can employ. If he can profitably undersell his rivals in an established trade he occupies the most advantageous position to which he can attain. No patents appear to be necessary to induce him to take this step whenever the opportunity offers, and to secure by suitable remuneration the aid of employees who by the exercise of their ingenuity can assist him in this direction. On the other hand, most of these advantages are lacking in the case of originative invention. For a new product there is no assured market; both the sale and the profits are problematical. It may be long before the utility and advan- 
tages of the new article can be made generally known. And the calculations and estimates as to the possible demand may not be realised. Not only so, but in addition to the outlay of capital in putting a new product on the market after the producer is satisfied of its value, this stage is often preceded by a long and costly period of experiment and trial, and, even after this period has been passed, unexpected difficulties are often met with when the manufacture is begun on a commercial scale. The writer remembers hearing many years ago, in connexion with the manufacture of glass bottles by a new machine, that it was not until after the venture had so far progressed that the article was actually on the market that the manufacture had to be abandoned. This was owing to its being found that the bottles turned out by the machine, although apparently sound, were all subject to a concealed defect which resulted in fracture in an apparently unaccountable manner when the bottles were brought into use.

The manufacturer, then, other things being equal, will naturally turn rather to intensive invention than to originative invention as a means of extending his trade. It is here that 
the patent system steps in to turn the scale in favour of originative invention. Holding a patent, the manufacturer who is enterprising enough to undertake the preliminary labour and expense has some hope that if he meets with success he will not be deprived of the means of recouping himself by the competition of imitators who, without risking anything, have perhaps been merely awaiting the issue of his exertions. If the issue is success, he may keep the business in his own hands during the continuance of the patent, and thereafter start with a long lead beyond all competitors, subject to the proviso that by his patent he is able to maintain the limited monopoly which it purports to grant. That, in spite of all the alleged defects in the patent system, patents often effectually protect the holder under these circumstances is shown by particulars as to the great value of these properties which from time to time become public. In a recent action in the Court of Appeal, for instance, it was given in evidence that the inventor of a submarine telegraph transmitter which was used by all the chief cable companies in the world was in receipt of royalties

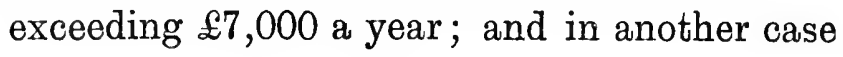


evidence was given of a premium of $£ 70,000$ being paid for an exclusive licence.

The general conclusion, drawn from the progress of agriculture, a comparison between the development of trade in Holland and in other countries, and from a consideration of the trade relations of the two classes of invention, is that, in the absence of the protection afforded by patents, while intensive invention is adopted freely, manufacturers do not so readily take up originative invention. On the other hand, in those countries where patents are granted industry is enlarged by the growth and application of originative invention. Remembering what was before shown to be the reparative function of originative invention in regard to those inconveniences to sections of the community which accompany the generally beneficial action of intensive invention, the final conclusion is that patents exercise a net influence in stimulating the growth of industry where stimulation is most needed, and thereby tend to counteract the effects of those causes which tend to diminish total activity and to generate unemployment. Greater definiteness and precision may perhaps be imparted to this conclu- 
sion by a nearer view of the various species of industrial invention which is the subject of the next chapter; after which the chief antiindustrial features of the patent system which operate by way of deduction from the full advantage derivable from patents will be examined, and the measures explained which have been taken to counteract them. 


\section{CHAPTER IV}

THE OPERATION OF PATENTS MORE CLOSELT CONSIDERED

$\mathrm{T}^{\mathrm{T}}$ will be seen later that, owing mainly to 1 the practical difficulty of fixing the precise limits of the monopoly to which an inventor is justly entitled, there have hitherto been associated with the English patent system certain anti-industrial tendencies. Evidence has, however, been found of a net beneficial action of patents in gross. Leaving, therefore, the consideration of these adverse tendencies on one side for the present, an attempt will now be made to trace more fully and present in greater detail the primary effects of patents upon industry and trade. To this end, the various species of invention composing the two main classes which have been called "intensive" and "originative" invention may be examined in turn. 


\section{Intensive and Originative Invention Distinguished.}

This enumeration may be prefaced with a somewhat closer definition of these two main classes of invention. There is no absolutely sharp line of demarcation between them. An improved article of somewhat greater cost may to some extent displace similar articles already in use, as electric light in part displaces other artificial light. To which class do inventions of this kind belong? The answer must be that all inventions which produce a result not previously attained belong to the originative class. A purchaser does not pay more for something that can effect only the result he can obtain by less costly means. The test, then, that determines the class to which an invention belongs is its effect upon cost. Whatever cheapens the means for attaining known results belongs to intensive invention. Whatever purchasers are prepared to buy at greater cost implies the attainment of a new result and belongs to originative invention. Broadly, this division agrees with the distinction between pioneer and improvement inventions which 
has long been recognised in the courts of law in dealing with patents. The two classes are typified by the leading cases of Proctor $v$. Bennis and Curtis v. Platt. As these legal classes have been distinguished for a different purpose, it is not to be expected that the correspondence would be exact; but those acquainted with these cases will recognise in "the attainment of a new result" the essential characteristic of the Proctor $v$. Bennis type of invention, and "the attainment of an old result in an improved manner" that of the Curtis $v$. Platt type.

\section{Intensive Industrial Invention.}

The most important kind of change which cheapens production is the substitution of machine for hand labour. This is often spoken of as though it were impressed upon the manufacturer by external compulsion. Thus Dr. A. Shadwell says: "It seems an inevitable law that if industries are to live they must change, and the great change is the substitution of machinery for hand work. ..." The preceding discussion has, however, exhibited this change not as a result of 
economic forces, but itself one of the primary causes whereby economic equilibrium is disturbed. It is not a mere result of competition, but is the chief instrument of competition. The introduction of machinery is one of the ways in which the competing manufacturer secures an advantage over others; and is, in fact, one of the primary causes of economic change.

The use of machinery not only enables the work to be done more quickly and with less fatigue to the workman, but it aids in many cases the subdivision of labour. It is seldom that a machine produces an article completely. The processes of manufacture are divided into a series of steps usually performed by different machines, and the duties of the workers are correspondingly divided among different groups. In other words, the organisation of the factory is improved. Another advantage that is derived is the intensification of the work in two ways: machine work goes on more regularly and without intermission and the space occupied in proportion to the output is reduced, both features being attended by their respective economies. 
With the use of machinery is associated another class of invention, individually of less import but very numerous and in the aggregate of great importance. These comprise modifications in the structure or design of the articles to be made, whereby mechanical production is rendered possible or is facilitated. The use of the machine reacts upon the article. Not only have machines been invented capable of making boots, but forms of boots have been invented which are especially adapted to the operations of the machine. And this is generally so in the case of machine-made products. The parts are standardised and made interchangeable, that is, made of uniform shape and size, so that each being produced in great numbers, the requisite selection to form the complete article can be readily assembled with the minimum of trouble and expense in fitting them together. These remarks refer more especially to the products of skilled labour.

But the substitution of machine for hand labour may occur either in regard to the skilled handicraftsman or in regard to unskilled labour. The immediate results to the displaced workmen may be similar in the two 
cases, but the ultimate consequences different. Thus dock labourers and skilled bootmakers may both be put out of work by the introduction of machinery in their respective occupations, but the former may be absorbed in other employment without much loss of status, if any, while the latter, losing the market for their skill, may either be driven into taking work of the unskilled class or in which, as when they become machine attendants, their skill is not utilised to its full extent. The re-absorption is therefore likely to be more slowly effected where the handicraftsman is concerned than where only the labourer is affected. Sometimes the substitution of machine for hand work makes no perceptible difference in employmentwhere the introduction takes place gradually in an expanding industry. The use of the milling machine in engineering works to do part of the work formerly done by engineers' fitters in all probability operated mainly to remove a check to expansion of the industry by increasing the effective supply of fitters. This is, however, by no means the universal rule.

From the business point of view large 
outlay of capital is justified if it results in dispensing with employees, and it is in this way that some of the most important economies in production are made. Speaking mainly with reference to the American adoption of automatic machinery for handling coal, ore, grain, and seeds in bulk, Mr. Zimmer says :- ${ }^{*}$

"In round figures it may be taken that the saving of one man's wages warrants the investment of $£ 1,000$ in machinery; hence in his quest for economy the engineer is ever on the alert to reduce the wages bill, and handle everything automatically."

By the time that readjustment to such changes has been effected there is a clear economic gain to the community in consequence of the increased productiveness of labour. But temporarily in the earlier stages there may be a net economic loss, in spite of the economy effected in the particular industry. This is because the maintenance of the dislodged men during the period of unemployment falls on others, and is not charged to the account of those to whom profit immediately accrues.

* "The Mechanical Handling of Materials" (1905), p. 4. 
A very numerous class of inventions by which cost of production is reduced comprises those which involve only the use or adaptation of existing works and organisations, and are carried out with ordinary plant, tools, and buildings. This class is probably not only the largest in regard to the number of inventions it includes, but also in regard to the scale on which they are practised. Inventions of this kind affect the bulk of the manufactures of the country, and form one of the chief means by which the continued cheapening of articles characteristic of modern industry is effected.

Two leading features distinguish this class. One is a tendency to promote further subdivision of labour, both in the individual workshop or factory as an accompaniment of improved methods, and also by the differentiation of trades which ensues on the multiplication of specialised processes. Another characteristic is the gradual and progressive nature of the expansion which takes place. The improvements may be adopted tentatively, and thus come into use without producing the disturbance of employ- 
ment and displacement of capital associated with the substitution of machine for hand work. Inventions of this kind generally comprise only relatively slight improvements which are mutually competitive; and while in the aggregate effecting substantial progress, seldom operate to bring about the extinction of existing trades.

Another class of inventions which effect the cheapening of commodities derive their importance from the large scale of the existing systems or works to which they relate. Many inventions consist in the overcoming of some difficulty or in the solution of some problem that presents itself in practice. And in some cases the difficulty or the need is felt only when the enterprise reaches a certain magnitude.

An example is furnished in the electrical distribution of motive power in factories and works. The older method of conveying the driving power to the several machines in a factory consists of the use of what is known as "line shafting." It is this line shafting, disposed overhead throughout the building, with its continual hum, and numerous pulleys from which leather belts descend to the 
individual machines, that to the untechnical observer gives the characteristic tone to the factory. More than one-third of the total power generated is often ineffectively consumed in distributing it by these means; and this waste imposes a strict limit to the extension of works supplied from a single source of power. Electrical power can be transmitted to all points over an extended area so economically as practically to remove this limitation, and permit of any extension that appears advantageous.

When such inventions remove a hindrance to the further expansion of existing works or systems, they permit of the fuller utilisation of all those advantages which belong to production on the largest practicable scale, namely, greater subdivision of labour, more complete employment of mechanical aids, fuller scope for the technician, higher organisation, and more economical management.

The conclusion was arrived at in the preceding chapter that the evidence of the actual operation of patents in gross indicates a comparative indifference of invention of the foregoing kinds to the encouragement 
which it is the object of the patent system to offer. This, however, applies strictly only to that portion of intensive invention which involves the employment either of existing plant or of machines and appliances of known kinds, which it is open to any one to adopt. It will presently be seen that one of the forms of originative invention consists in furnishing new machines and appliances designed to subserve the purposes of cheapening production. This leads to a considerable qualification of the broad conclusion already stated, the exact specification of which will be attempted after a closer view has been taken of originative invention.

\section{Originative Industrial Invention.}

We now turn to the second of the two principal kinds of invention, namely, those which result in the establishment of entirely new manufactures. The most numerous of these resembles one of the preceding groups in being producible mainly by the use of ordinary plant, tools, and buildings, and involving only adaptation of existing works and 
organisations. They differ from that group in offering altogether fresh outlets for activity and applications of capital, as contrasted with competitive disturbance of existing trade. It is largely by these that the reparation of those partial evils which have been traced to the mere cheapening of production, when it occurs alone, may be effected. Their function is therefore of the highest importance. The manufacturer who finds his former trade diminishing meets in these the opportunity for restoring the balance, by adopting the manufacture of those articles the most closely analogous to those he is accustomed to, and the best fitted to his works and plant. In like manner the skill of his workmen finds renewed application, and unemployment is thereby checked. This group also differs from the previously described group in being not so essentially competitive. In a certain degree new products compete with all other commodities for the favour of the consumer, but such inventions seldom or never compete with each other or with established industries in the same way that these latter do among themselves. The new wares are scarcely ever exactly equivalents one of another or 
of those already in use. Each possesses its own peculiar advantages under appropriate conditions. For example, incandescent gas fittings appeared after electric lighting was fairly established. Gas may compete with electricity, but not with the intensity which would characterise the rivalry of two electric light companies in the same district. The telephone may compete with the telegraph to some extent, the motor-bus with the railway, but in the main one is complementary to the other.

One of the principal kinds of new product falling in this group is special machinery and appliances designed to displace or to facilitate hand work. It is clear that in regard to these, successive effects different in kind may ensue ; the first the expansion of trade due to the growth of a new manufacture, the second those already sketched in connexion with the use of machinery. If, however, the new machinery is for export, the secondary consequences in the country of origin are modified, and for a long period the effects may not be appreciable. In the circumstances which prevailed among the chief producing countries of the world during the second half of the last century the 
secondary consequences of enormous manufactures of labour-saving machinery were not experienced in this country. The primary effect was to assist the absorption by the manufacturing trades of the large body of labour gradually displaced by the cheapening of corn and transferred from the country districts to the towns. The subsequent consequence was to assist in hastening the appearance of that competition in the world's markets which in recent times has been the leading feature of the relationship between industrial nations.

There is one case, however, in which, even if this kind of product is for home use, the secondary consequences do not ensue. It is the case in which the new machinery and appliances are for the manufacture of some entirely new product-that is, when it is intended to subserve the purpose of those inventions that fall into the next group.

The last group of inventions to be singled out are those pioneer and creative inventions which more or less completely demand for their exploitation the provision of new plant. This kind of invention, though the rarest, is, when it is forthcoming, the most effective 
in furnishing new outlets for enterprise and counteracting the partial inconveniences and industrial disturbance due to the progress in old manufactures outstripping the provision of new ones. It is here that the genius of the inventor as an individual is seen at its best; but it is probable that the total effect of inventions falling in the preceding class is greater than that of this class, and we are not at this stage of our inquiry concerned with the personal merit of the inventor. Whenever a pioneer idea comes to be put into practice innumerable difficulties and problems present themselves, and the final success depends as much upon the successful treatment of these as upon the original conception. In many instances what appear to be alternative methods of overcoming the obstacles met with in practice are offered, but these are seldom true alternatives; usually, practical conditions determine which one is the best for each application or development of the main idea. Each contributory finds its place as an essential component in the final achievement. In the history of the arts the merit of the individual inventor stands out clearly; but when the inquiry is into economic consequences the 
work and personality of the individual is merged in that of the entire body of inventors and others who take part in the building up of the new industry.

\section{A Re-statement of the Primary Effect of Patents.}

We are now in a position to state more exactly and in fuller detail the primary industrial and commercial effects of patents in gross: Originative invention is fostered and encouraged by patents, and reaches its full development only under a patent system. Originative invention comprises the introduction of all new articles and products, whether or not their production demands the provision of new plant. In all cases, but especially when it does, invention of this kind is the chief means whereby unemployment generated by intensive invention is counteracted and trade enlarged. New articles and products must be understood to include all those by or in which any new result is attained; and the attainment of new results is indicated by any increase in value attached to them by purchasers. Inventions falling 
in this class are not generally so essentially competitive with others in the same class as are intensive inventions, and therefore entail to a less degree the consequences of competition. The new result attained in the case of new machinery and appliances may often itself be the introduction of intensive invention; and to that extent intensive invention is dependent upon originative invention, and is promoted by the patent system.

Intensive invention, on the other hand, is generally indifferent to patents, except where it is due to the employment of machines and appliances of kinds not already known. It is essentially competitive, and continually, when acting alone, tends to reduce total industrial activity and the area of employment.

Briefly, then, patents foster originative and originative-intensive invention, with their respective consequences; but exercise little or no primary influence upon invention which is strictly and solely intensive. 


\section{CHAPTER V}

ANTI-INDUSTRIAL FEATURES OF THE PATENT SYSTEM

TAVING found definite evidence of the 1 fulfilment of the avowed purpose of patents in regard to that class which has been designated originative invention, that is, pioneer or creative invention which results in the establishment of manufactures of new products, the next matter that claims attention is the inquiry whether patents produce any indirect or secondary economic consequences of a disadvantageous character. Any such consequences, wherever they occur, must be regarded as a deduction from the possible utility of patents, tending to diminish the net value to the community of the patent system. Many defects of this kind have from time to time been pointed out, and at one time there existed a considerable body of opinion to the effect that the disadvantages attaching to any 
patent system were so serious and so incurable that they altogether outweighed any advantage the system might possess. This is shown by the comment in a leading article in The Times on the morrow of the debate in the House of Commons, upon a motion by Mr. Macfie, in the year 1869, that "if we may judge from the discussion upon the subject in the House of Commons last night, the day is at hand when this branch of our legislation will be wiped out of the statute-book"; and by the similar observation in the Economist: "It is probable enough that the Patent Laws will be abolished ere long." Since that time, however, opinion has definitely swung round in favour of remedying proved evils, and several Acts of Parliament directed towards that end have been passed. The obstructive use of patents and their employment as a means of encroaching on the rights of the public, as described below, has been dealt with in this way, notably in the Patent Acts of 1902 and 1907. These are the chief matters in regard to which complaints have been made concerning the working of the patent system in recent years, and so far as these Acts achieve their purpose they will go far towards neutralising those indirect 
consequences of patents which have been found to be disadvantageous; but it is too early yet to judge how far they will succeed in removing the causes of complaint.

\section{Obstructive Use of Patents.}

Chief among the mischievous tendencies of patents is that they are capable under certain circumstances of being used to obstruct the introduction of improvements and to prevent the establishment of new manufactures. This effect is especially marked when patents are held by foreigners and the manufacture is carried on mainly or entirely abroad; and it has been the subject of much complaint in recent years. The adoption of intensive invention and of originative invention in this country may both be obstructed in this way, but the operation is not exactly the same in the two cases. By the application of intensive invention abroad it may be possible to import manufactured goods at lower rates than they can be made in this country, while the home producer is debarred from cheapening his processes by reason of the existence of patents in this country, perhaps obtained for that 
very purpose. In that case the patents in this country exert a tendency to transfer a portion of an established industry to a foreign country, and their operation is therefore inconsistent with the motive on which the grant of patents is based. It may, however, be open to the home manufacturer in such a case to attempt to meet competition of this kind by the introduction of equivalent or superior improvements designed to counteract the advantage possessed by the foreign competitor. In the case of originative invention emanating from abroad he cannot even do this. In this case the patents in this country may be made to subserve the attempt in the first place to prevent the new manufacture from being instituted in this country in any form, and in the second place to deprive the manufacturer here of any opportunity of improving on the main idea, or of introducing any new manufacture dependent on the use of the patented product. These results may be effected by discrimination in the supply of the patented product, coupled with a refusal to grant liceuses to work under the patents. The harm is done to the home industry in the case of intensive invention by free importa- 
tion, but in the case of originative invention either by its non-importation or by discrimination against certain manufacturers.

The chemical industry, which, measured by the value of the export trade, stands fourth in order of importance among the manufacturing industries of Great Britain, is believed to have suffered severely in this way. Mr. Levinstein states, in a paper approved and adopted by the Manchester Chamber of Commerce in 1900: "The great majority of chemical inventions which have been made during the last twentyfive years are derived from the domain of organic chemistry, a field of science which has been, until recent years, sadly neglected by Great Britain, but which has been fruitful in its application to the arts by founding and establishing a number of new branches of industry. Amongst them may be mentioned the manufacture of coal-tar colours ; the production of artificial food, as, for example, of albuminous substances; the artificial production of flavours and perfumes, hitherto only producible by the chemistry of nature; the production of valuable antipyretic, antiseptic, and other medicinal preparations ; the manufacture of sweetening substances, of photo- 
graphic materials, and photographic developers and assistants."

"All these new branches of industry, representing millions of money and giving employment to thousands of workmen, and many other collateral industries which have sprung up pari passu with their establishment, have principally their home in Germany, and the very large number of patents which have been taken out for these various productions are chiefly owned by our competitors, and scarcely any of them are worked in this country. The manufacture of the said products is in the hands of powerful foreign corporations or syndicates."

Complaints of this kind are not confined to the chemical industries. A similar complaint was made in regard to the absolute exclusion of a valuable loom from this country by the use of patents. The foreign makers, it was said, refused to supply any manufacturer in this country with this machine at a time when they had already supplied upwards of 70,000 to manufacturers in other parts of the world. The motive was stated to be unconnected with any commercial advantage to the makers; but, whatever the motive, the British patents were 
in that instance used in such a way as to prevent, to the detriment of the textile industry in this country, the home manufacturer from making use of the improvement. Other articles in regard to which similar complaints have been made comprise printing machinery, typewriters, telephone apparatus, machine tools, and motor-car parts.

The use of patents granted in this country to foreigners merely to preserve a close market in the United Kingdom for products manufactured abroad is believed to have occurred to a large extent also in other industries. Colour is given to this belief by the very large number of patents obtained here by foreigners as compared with those granted to home inventors and to foreigners in Germany and in the United States. In the year 1906, while the numbers were 3,310 and 3,292 in the two latter States respectively, the number in the United Kingdom was 6,255. Of the total number of patents at present in force in England, between 65,000 and 70,000, probably more than 30,000 are held by foreigners. These facts show that at any rate a considerable opening is afforded for action detrimental to the interests of this country, 
whether or not it is utilised to its full extent.

The close connexion between foreign trade and invention has already been commented upon. It would not be surprising, if the views expressed are well founded, to find some reflection of this adverse use of patents in the statistics of trade. There is in fact a feature in the foreign trade of this country of which the explanation has been sought in various directions, but which may in part be the outcome of the obstructive use of patents. This is the tendency of the exports of goods classified by the Board of Trade as wholly or mainly manufactured to increase at a slightly declining rate as compared with the total exports of domestic produce. Between the years 1891 and 1906 this proportion fell from 85 per cent. to 81.3 per cent. The connexion between the effect and the suspected cause cannot be traced with any certainty, but it is somewhat remarkable that, as has been shown in a former section, among the principal manufacturing countries England is the only one except Holland where a change like this is seen. It will be remembered that in Holland, which is the only country which grants 
no patents for inventions, the decline in twenty years was from $27 \cdot 2$ per cent. to $17 \cdot 1$ per cent., while in all the other countries an increase took place. The conclusion was arrived at that this trend in the trade of Holland could be accounted for only as the consequence of the absence of a patent system. And it does not seem unreasonable to suppose that a similar though less pronounced tendency in the trade of this country may perhaps be accounted for in part by a widespread use of patents in a way which has been shown to be likely to produce effects of this kind.

In order to prevent the misuse of patents in this manner a clause was enacted in the Patent Act of 1907 commonly known as the "Coinpulsory Working" clause. This clause provides that if the patent is worked exclusively or mainly outside the United Kingdom, any person, after four years from the date of the grant, may apply for revocation. The patent, on proper proofs being forthcoming, may then be revoked unless the patentee gives satisfactory reasons for not working the invention in this country. The revocation may take place forthwith, or after a reasonable delay, granted in order to give the patentee an 
opportunity to commence working in this country. Although in the main directed against the obstructive use of patents by foreign holders, the terms of this section are general, and it applies equally to the home patentee. It may be noticed that to call this provision a compulsory working clause is somewhat of a misnomer. Working the invention is made a condition of the continuance of the patent only if the circumstances are favourable to the invention being worked in this country. In any case three courses are open to the choice of the patentee: to work the invention; to prove that the circumstances are unfavourable to such working; or to surrender his power to prevent others from using the invention.

Many objections have been brought against this enactment, based chiefly on the ground that it might be made to operate unfairly against the poor and deserving inventor. It has been said, for instance, that manufacturers have only to refrain from taking up an invention during the four years' period, and they will then have the benefit of the invention without payment. Other cases of possible hardship have been suggested. Objections of 
this kind are evidently inspired by distrust of the safeguards provided in the section in the interest of patentees whose non-working is not intentionally obstructive. A very wide discretion in regard to this matter is placed in the hands of the authorities who will have to administer this part of the Patent Law.

The position cannot be better summed up than in the words of Sir Edward Grey, who stated in answer to a question in the House of Commons: "Section 27 does not require that every patent should be worked in this country. It merely provides that if it can be shown that after the liberal interval allowed by the Act a British patent is worked mainly or exclusively abroad, any person can call on the patentee to show why his patent is not worked to an adequate extent in this country. If the patentee can give an explanation satisfactory to the Comptroller and the Court, his patent will not be revoked. If he can show that further time is required to enable him to work his patent to an adequate extent, the necessary time may be allowed by the Comptroller, or, if the Comptroller refuses it, by the Court."

A requirement in regard to working has 


\section{ANTI-INDUSTRIAL FEATURES}

existed in the patent systems of most countries, the most notable exceptions having been the United States and the United Kingdom. And it is said that experience has shown that a provision of this kind cannot be enforced. Evasions, at any rate, are countenanced in many countries. Thus periodical advertisements offering to grant licenses, known as "working by advertisement," or the occasional putting together of one or two machines, have been allowed to piss muster. Here again the extent and operation of the requirement in this country must depend almost entirely upon the manner in which the discretion allowed under the section is exercised.

Some controversy has taken place on the question whether or not the so-called "compulsory working clause" is or is not Protective in its nature. On the one side it is said to put pressure on foreign manufacturers to set up manufactures in this country for reasons other than those of commercial advantage, and that therefore the provision is essentially Protective. On the other side it is said that the patent itself puts the holder in a privileged position, and that the revocation of the patent, 
throwing the manufacture open to all the world, is merely the removal of an artificial interference with trade, and is therefore essentially consonant with Free Trade principles. Whatever interest may attach to this question from the point of view of current politics, it is not necessary to pursue it further in connexion with the present subject, beyond remarking that the readiness of the leading parties each to claim that the measure is a direct outcome of their respective tenets shows how very general is the expectation that the measure will prove advantageous.

At the time of writing it is not possible to forecast the precise effect of this provision upon home industries. The results already accomplished, however, are succinctly stated in the following paragraph extracted from the Journal of the Royal Society of Arts * :-

"Already some thirty foreign firms--many of them conducting operations on a large scale-have begun, or are about to begin, operations in this country, most of them choosing the North of England as the scene of their operations. It is said that as a rule

* "Journal of the Royal Society of Arts," vol. lvi. (September, 1908). 
the foreign manufacturer is providing a factory many times larger than is really necessary for the construction of his patented article, his explanation being that he cannot run works in England on patents alone, and he intends therefore to manufacture in this country goods thai have hitherto been imported ready-made. So far as can be seen at present the Act musi profit British labour. It is said in some quarters that these manufactures, at any rate the German ones, will be worked by foreign staffs, but this is not the case at present with Messrs. Meister, Lucius, and Brünning (Limited), of Germany, a company with a capital of $\$ 11,000,000$, which has just erected a new chemical factory at Ellesmere Port. Here all the workers employed are English, with the exception of a few German overseers. The working of the Act will be watched with keen and anxious attention, for British manufacturers are beginning to realise that foreign competition is about to invade their own particular territory, and that there will be a fair but strenuous fight on British soil for British custom. That is not a prospect that can be viewed altogether without anxiety when the perfection of German organisation 
is remembered. The German things to be manufactured in England will be mostly aniline dyes, pottery, plant for gas-making, rifles, plated goods, electrical contrivances, furnaces, sanitary appliances; the American, typewriters, safety razors, phonograph records, shoes, telephones, and wire roofing."

The provision in regard to working the invention is supplementary to a provision having a similar object which in one form or another has been in force since it was introduced for the first time in Mr. Chamberlain's Patent Act of 1883. The remedy referred to consists of the compulsory grant of a licence by the patentee to the aggrieved party on terms fixed by the tribunal authorised to determine the matter. These provisions are generally regarded as having failed, largely on account of the cumbersome nature of the procedure, and of the great expense thereby entailed, and in the most recent Patent Act the section has been remodelled with a view to removing these objections.

Oppressive Exercise of Patent Rights.

Another mischief which has been found to arise in connection with patents is that they 
can be used to control an industry not only during the life of the foundation patent or patents by which the pioneer invention is protected, but subsequently for an indefinite period. This is effected by attaching conditions to the use of the patented article. The most striking example of this is the way in which certain American boot-making machinery have been employed in this country.* Boot-making by machinery has been practised in the United States for more than thirty years, and it is long since the expiry of the foundation patents. But small improvements in the machines are continually being introduced, and through these the original patentees or their successors have retained control of the industry. It must be admitted to the credit of the machines that they are of such efficiency that the boot manufacturer has been compelled to adopt them or go to the wall. In adopting them, however, he has not been allowed to purchase them outright, but has been compelled to take them on a lease of twenty years, agreeing to

* "Boot-making Machinery," by Dr. A. Shadwell, The Times Engineering Supplement, December 11, 1907. 
pay a royalty on the working. These leases not only tie him to the use of that machine for twenty years, but contain stringent tacking or linking provisions which practically result in a complete surrender of his industrial freedom. The user of the machine by the terms of the lease pledges himself not only to use the machine and no other for the performance of a particular process, and as many machines of the same kind as he has work for, but also not to use it on boots or parts of boots on which the preceding processes have been performed by the machines of any other maker. For instance, the lease of a machine for putting in screws contains the provision that it is not to be used in the manufacture of any boots and shoes except those which have been lasted upon machines supplied to the user by the lessor on similar terms, and so on through other processes. It is also provided that the owners of the machine shall have the right of access at all times for the purpose of altering, repairing, improving, or adding to it, or determining the nature or extent of its use. By the continued introduction of improvements, coupled with like conditions 
of increasing stringency, the monopoly obtained by the American machine makers might perhaps have been continued indefinitely if measures had not been taken to combat the evil by statutory enactment.

Another instance of an extension of the monopoly is afforded by the condition attached to the sale of certain lighting appliances. These were sold for use only with a patented burner made by the same company that supplied the appliances, and their use with any other burner constituted infringement of the company's patents. The legality of this policy was questioned on the ground that it was in restraint of trade, but that the holders of the patents were acting within their legal rights was affirmed by the Court of Appeal, broadly on the ground that as the patentees could prohibit the use of the patented appliances altogether, they were entitled to exercise the lesser restriction of attaching any condition to the use which they might think fit.

By the Act passed in 1907 all future contracts and conditions of this kind are rendered nugatory, and provision is made for equitably terminating any such contracts at present in force. 


\section{Predacious and Bluffing Uses of Patents.}

A further serious mischief associated with the grant of patents arises in connexion with the means by which the monopoly is conferred. The formal grant does not itself define the scope of the monopoly. This is set out in the specification which the inventor is required to deposit prior to the issue of the patent. The specification is the declaration to the world at large of the invention which others are prohibited from practising, and the depositing of this specification without any other proof of the actuality or practicability of the invention than is contained within the four corners of the document itself is the primary condition of the grant. The way to abuse is thereby opened in two directions. The opportunity is afforded for vague patents to be taken out, not for practical manufactures, but for mere ideas of what may one day be possible, in the hope either of blocking the way to subsequent improvers or of levying toll on those who may subsequently make a practical success of the proposed manufacture. Such patents may lie dormant for years, only to be brought forward as master patents when the really 
useful and practical invention appears. They have been aptly named "blocking" patents and "predacious" patents, according to the use to which they are intended to be put. It would be invidious to give examples, but the published records of the Patent Office contain hundreds of vague patents of which it would be difficult to find any other explanation than that they are intended for such uses. They are to be found chiefly in the electrical and chemical ields. In organic chemistry it is possible by theoretical deduction to fix the potential existence of a large and almost unlimited number of substances which may never have been seen or made by any one. The applicant for one of these patents simply enumerates all the possibilities he can think of, puts them into his specification, and besides protecting something which he may have discovered often includes a large number of merely speculative results. His object is to cover as large a field as possible in order to anticipate further improvements within or on the borders of the domain of his speculative invention. An expert chemist might be engaged for several years in his laboratory in actually producing those bodies which may possibly be 
obtainable under the patent. But if any inventor or manufacturer should discover among these possibilities a really valuable article, the owner of this fanciful patent is ready to pounce upon him as soon as its production becomes a commercial success. This, in brief, is the description given by Mr. Levinstein in the paper above referred to of the way in which patents can be misused in the chemical field. Something has been done in the direction of checking this practice in the Patent Act of 1907 by the strengthening of the provision relating to the requisition of a particular description which every specification is supposed to furnish of the manner in which the invention is to be put into practice, and by the enactment that samples, in the case of chemical inventions, must be deposited on the requisition of the Comptroller-General of Patents.

The other direction in which the way is opened to abuse is in the opportunity offered of framing the description or claims in the specification so widely as to include within the scope of the patent invention which is already public property. In many instances this is due to ignorance of what has already been 
previously done or proposed. But the innocent cases in which the scope of the patent is unduly extended merge into the intentionally " bluffing" patent. There is nothing on the face of it to distinguish a patent of this kind from one based on a genuine inrention, and that section of the manufacturing public to whom the specification is more particularly addressed may naturally be deceived as to the extent of the prohibition which is legally enforceable. The fear of becoming involved in costly and uncertain litigation may restrain the interested parties from contesting the ostensible rights of the patentee even when they are not entirely deceived, and by judiciously playing upon that fear the astute holder may succeed in making his monopoly effective to a sufficient extent for his purpose. The effect of the action of the patentee in such cases is the same whether the undue extension of the scope of his claim is innocent or intentional; and where such patents are numerous, as under the system of granting patents upon mere solicitation, the aggregate effect may constitute a serious invasion of the rights of the public. The report of the Committee appointed by the Board of Trade in 
1900 , to inquire into the working of the Patents Acts and presided over by Sir Edward Fry, states: "Both from the evidence before us and from the knowledge possessed by members of our Committee, we are of opinion that the grant of invalid patents is a serious evil, inasmuch as it tends to the restraint of trade and to the embarrassment of honest traders and inventors."

In order to explain the measures taken to minimise this evil the office fulfilled by patent "specifications" must be briefly referred to. The purpose of the "specification" of the invention, which an applicant for a patent is required to furnish as a condition of the grant of the patent, is twofold. On the one hand, it is intended to embody full information as to the way in which the invention is to be put into practice, so that on the expiry of the monopoly the invention shall be available to the whole community. On the other hard, the specification is intended to define precisely the scope of the monopoly so that during the continuance of the patent others may be informed clearly what the patent prohibits them from doing. The official examination before the year 1905 was 
directed to.,ascertaining whether the specification was sufficient, merely in regard to the former of these two purposes, and to the requisition of amendment if it was not found to be so. Since the year 1905 a further investigation has been made in regard to each application for a patent; and if the specification is found to set up a claim to an invention previously claimed or described in any patent application completed within the preceding fifty years the applicant is called upon either to amend his specification or to submit to an endorsement thereof by way of notice to the public. It results that in about 3.3 per cent. of cases the patent is issued with this distinguishing mark, in about 8.2 per cent. the application is voluntarily abandoned, and in other cases that the patentee is caused to frame his specification so as not to claim, or appear to claim, something which the patent records show to be public property. The action of the Patent Office is confined to securing a fair description of what purports to be the invention, or, in the alternative, to issuing the patent with its warning mark. However small the point may be which the inventor can 
show has not been wholly and specifically included in any prior patent specification, provided that the distinction relied upon by the inventor is clearly set out, the patent is granted generally without endorsement; and the reader into whose hands the specification may fall is as far as possible put into a position to judge for himself whether the alleged invention possesses any real value or merit.

It should be borne in mind that a distinction which on paper appears trivial may prove in practice to be of great importance. The only sure criterion of the reality and value of an invention is, in fact, the result achieved. This point is forcibly and authoritatively explained in a recent judgment by Lord Justice Fletcher Moulton, who said: "But when you come to machines which with this demand upon them still give uniform success, I think any tribunal will be very careful before it applies its ordinary ideas of what are mere idle and trivial changes to those alterations which have resulted in a success so triumphant. So that I approach the consideration of novelty in this case, i.e., of the importance of apparently slight variations in the combination, in a very humble spirit, 
willing to be taught by those who know the practical performance of the machine, and are able to judge of the means which render that practical performance so successful. I remember very well a machine for printing newspapers and turning them out in a folded form, in which the whole difference between hopeless failure and most valuable commercial success depended on a trivial change in the arrangement between the nose of a plough over which the sheet was bent, and certain rollers which actually folded the paper after it had been thus bent, a matter which, if you read it on paper, seemed to be perfectly trivial, but which, I have no doubt, required very long-continued experiment in order to arrive at the proper arrangement and demonstrate its importance, but which, once arrived at, actually turned failure into success."

In most cases evidence of results can only be forthcoming after the patent has been granted and the invention brought into use. At the stage when a patent is being applied for it is only to be expected in general that little or no evidence of this kind will be available. But by the compromise between the indiscriminate grant of patents and the 
power of rejection usually associated with official examination which has been effected in this country, the inventor is safeguarded against the possibility of refusal of the grant based upon official misapprehension; while at the same time the public are to a great extent protected from imposition by means of patent specifications which are misleading.

There is yet another way in which an illegitimate extension of the monopoly conferred by a patent may be attempted. This is by means of the vague threat conveyed by the marking of the article with the word "Patent." It is a punishable offence to make a false representation in this way; but there is no obligation on the manufacturer to distinguish the patented feature or features, or to specify the patent under which some patented improvement is really embodied in the marked article. The effect of this, especially when, as in the case of a machine, the article is complex, is to make it uncertain whether or not any part whatever of the machine may be lawfully copied, or whether any improvement suggesting itself to an observer could or could not be used without licence. The warning implied in the use of 
the word "patent" extends, in fact, to the whole machine and to every part of it, when possibly the matter actually patented may be some very insignificant feature. The use of the threatening mark under these circumstances, without giving any clue to the identification of the patent, tends towards an improper extension of the scope of the patent similar to that produced by a wide and deceptive specification. The measures taken to guard against the issue of misleading specifications might indeed be very largely nullified unless they were accompanied by some restriction of this practice.

It is, however, now provided by the Patent Act of 1907 that a patentee shall not be entitled to recover damages for infringement from a defendant who proves that he was not aware, nor had reasonable means of making himself aware, of the existence of the patent; and it is also provided that the marking of the article with the word "patent" or any similar marking shall not be deemed to constitute notice of the existence of the patent unless the number and year of the patent are also quoted. This to a great extent will destroy the deterrent effect of the threat 
conveyed by the vague mark "patent" standing by itself, and it is reasonable to suppose that, in consequence, this mark will in future be accompanied by more specific particulars. It will thus often become apparent on reference to the specification to which attention is directed that the claim which the patentee is entitled to make is of a very restricted character; and in effect the monopoly will accordingly be reduced to its rightful dimensions.

Bismarck's Indictment of the Patent System.*

The obstruction of improvement and the encroachment on the rights of the public associated with patents in the manner already described are the chief objections to patents in modern opinion, which generally acquiesces in the existence of the system in some form. But many objections have from time to time been brought forward which strike at the foundation of the system in any form. It is interesting to examine how far any of these throw light on the economic aspects of the

* "Recent Discussions on the Abolition of Patents for Inventions" (1869), p. 185. 
matter. A masterly summary of these objections is contained in an indictment of the patent system addressed by Bismarck in 1868 to the North German Federal Parliament, and it will be convenient to select from this message those parts which have a modern application, omitting those which referred particularly to the circumstances of the time at which the note was formed. The message says :-

"To an argument which has been repeatedly urged-i.e., that the granting a temporary exclusive right is indispensable (so as to secure for the meritorious inventor a reward adequate to the mental labour and money expended, as well as risk incurred, in order that there be no lack of encouragement to the inventive genius) - the objection may be raised that the remarkably developed system of communication and conveyance nowadays, which has opened a wide field to real merit, and enables industrial men promptly to reap all benefit of production by means of enlarged outlets for their articles, will, generally speaking, bring those who know how to avail themselves before others of useful inventions to such an extent ahead of their competitors, that, even where no permanent 


\section{THE ENGLISH PATENT SYSTEM}

privilege is longer admissible, they will make sure of a temporary extra profit, in proportion to the service rendered to the public."

"It is, in fact, in the peculiar advantage produced by the early bringing into operation of a fresh suggestion of their minds, that the remuneration of those lies who, through cleverness and steadiness of purpose, succeed in satisfying existing wants in a manner less expensive and superior to what previously was the case, and notwithstanding do not obtain any monopoly."

In regard to this it may be pointed out that the "argument" stated at the beginning of the passage evidently applies only to what in the preceding discussion has been called originative invention, while the reply has in view intensive invention. Qualified in this way, there is no opposition between them, and both may be admitted as consonant with the conclusion as to the economic action of patents arrived at as a result of the foregoing considerations.

Again :-

"As for the often much-commended socalled 'application system' [that is, the system under which patents are granted 
without official inquiry into novelty] it would by no means really answer the purpose ; even without considering the theoretical objections which might be urged against it. Its practical results have been far from giving satisfaction wherever it has been adopted. The complaints of the abuses and impediments industry suffers under, which are brought about by the overwhelming mass of patents, for the most part taken out with a view to swindling speculation, the unpleasant experience acquired by those who take all legal means so as subsequently to contest and defend patents granted without previous inquiry being made, have led to a reaction of public opinion in favour of abolishing the system."

This passage adverts to those mischievous uses of patents already briefly recounted, and in regard to which the counteracting legislative measures have also been indicated.

"Experience has, however, taught that in most instances patents do not fulfil their mission; that on the whole they have not proved an actual benefit, either to the proprietor or the public; that the profits have gone just as often into the pockets of strangers as into those of the able inventor." 
This objection, so far as it applies to the public, cannot be admitted by any one who accepts the evidence regarding the beneficial effect of patents in promoting the adoption by manufacturers of originative invention. So far as it refers to the inventor it does not touch directly on the economic question.

"Against the stimulating influence of monopoly upon individuals we must, however, in a period so extremely favourable to industrial progress, not underrate the very important point that it also checks the quick and fertile development of a new thought, which, when totally free, might be expected to spring up in a higher degree from the competing labours of all."

This is unquestionably a very forcible objection, which, with the increase in the number of patents, gains in strength from year to year. It applies mainly to intensive invention, which, on various grounds, especially the continuous improvement of the agricultural arts equally in those regions to which patent protection is extended and those to which it is not extended, it has been concluded is to a large extent independent of the patent system. The precise extent to which the 
general adoption of this class of invention, is retarded is difficult to gauge; but, while allowing that some delay is entailed, there are compensations which can be pointed out on the opposite side.

Minor improvements are continually being introduced in practice which are never made the subject of patents. Naturally those who adopt them desire to retain as far as possible for themselves the advantages which ensue. They are unwilling that others, especially trade rivals, should obtain too intimate a knowledge of their procedure. This is illustrated by the following extract from a recent paper read by Mr. Robert Buchanan on "The Application of Science to Foundry Work" before the Society of Arts:-*

"The annealing of malleable castings is still very largely empiric, and not much advanced in knowledge or practice during the hundred years which have elapsed since Lucas patented the process. This result is almost wholly due to the 'closeness' with which each malleable founder keeps secret the details of his operations. The silence which accom-

* Journal of the Royal Society of Arts, February 14, 1908. 
panies the manufacture of malleable castings would persuade one that the methods are secret; whereas the principles are well known."

This state of affairs may perhaps be more noticeable in the trade referred to; but it is typical of what in some degree obtains in all trades. The power of this tendency to "check the quick and fertile development of new thought" is shown by Mr. Buchanan's statement of the consequences produced in the malleable iron trade; and these consequences are probably more permanent in regard to unpatented matters than in regard to those which are patented. It must also be remembered that the average life of all patents granted in this country is under five and a half years; and that, in connexion with every patent full information as to the procedure to be adopted in order to put the invention into practice has to be placed on record in the specification. These specifications are published far and wide, and the information they contain is made available to all who desire to make use of it. So far, then, as the patent system is taken advantage of in connexion with the minor improvements 
which manufacturers might otherwise guard jealously as trade secrets, their general adoption and fertile development is more likely to be expedited than retarded.

One more extract from Bismarck's message completes the series:-

"Nor can much importance be attached to the apprehension that, should the Patent Law be repealed, inventors might show more disposition towards keeping new inventions secret from the public; for, even assuming the abolition to be an incitement to keeping inventions secret, yet it cannot be admitted that any prejudicial change from the present state of things would take place. Even now, under the rule of the Patent Law, it is a recognised fact that to such methods of fabrication and resources as admit of being kept secret, the very secrecy affords ampler protection than the patent itself. By thus drawing the conclusion that those inventions which might eventually be kept secret are so at the present time as well, no actual prejudice will be caused by one measure being in force rather than the other."

From the nature of the case direct evidence bearing on this point is not easily obtainable, 
but indications may be met with from time to time that secret processes are more numerous than they should be if the patent system really effected all that is expected of it. The statement, however, is not that actual harm is done by the patent system in this respect, but merely that in a certain direction it is ineffective.

Fears have been expressed that one of the unintended results of the Patent Act of 1907 will be largely to increase the number of inventions worked as secret processes. This is by reason of a new provision which removes the risk of invalidation arising solely from the premature publication of an invention which is being worked experimentally, or is otherwise accidentally disclosed, on the eve of an application for a patent. It has been suggested that this provision can be utilised to enable an inventor to work his invention commercially in secret, and to defer applying for a patent until discovery takes place or becomes imminent. This suggestion is based upon the belief that the fact that the invention has been used commercially would not impair his right to a patent applied for subsequently. Legal experts do not, however, 
agree on this point, and, in the opinion of the writer, there are strong grounds for believing that commercial working of an invention-that is, working entered upon for the sake of profit from the sale or use of the invention-would invalidate a patent obtained upon a subsequent application.* Unless the contrary opinion proves to be well founded, the anticipation that this provision will act as an additional inducement to the secret working of inventions is not likely to be realised.

* "The Law and Practice relating to Letters Patent for Invention," by R. W. Wallace and J. B. Williamson (1900), p. 96. 


\section{CHAPTER VI}

EVIDENCE AFFORDED BY LONG-LIVED PATENTS

THE undesirability of allowing the path of I the manufacturer to be cumbered by useless patents has been recognised in this country for many years, and the system of patent fees has been designed to discourage the continuance in force of useless patents. A patent is granted for a period of fourteen years, subject to gradually increasing annual payments, beginning with the fifth year. These fees have the effect of extinguishing at the end of the fourth year about 65 per cent. of all the patents issued. The subsequent rate of extinction varies between 20 and 25 per cent. of those remaining at the end of each year, with the result that those that survive the thirteenth year and remain in force for the full period of the grant number less than 5 per cent. of the original issue. Thus of the 12,042 patents granted in the 
year 1894, 503 were continued for the fourteenth year by the payment of renewal fees in the year 1907. Possibly many valuable inventions are embodied in patents which expire before the full term has run out; but without assuming that those that are allowed to lapse are valueless from the beginning, it is clear that the most valuable and important are to be found among those which live the full term. As these patents in general have at the most a year to run, there is not the inducement which is present during the earlier years to pay fees speculatively; and it is safe to infer that the renewal of a patent for the fourteenth year is usually an indication that the invention has been an industrial and commercial success.

It is therefore to be expected that some useful information as to the working of the patent system might be obtained from a survey of patents which have satisfied this test, and in particular that such a survey might throw some further light on those aspects of the patent system which have been discussed in the preceding pages. With this object the writer has compiled a list of those patents, referred to above, granted in 1894 and renewed 


\section{THE ENGLISH PATENT SYSTEM}

during the year 1907 for the fourteenth year. The results of an examination of this list from different points of view are generally in agreement with the conclusions which have already been arrived at. It is, of course, not always easy to say from an inspection of the contents of a specification in what economic class the invention ought to be placed; there are no hard-and-fast lines of division between the several classes of invention. But, so far as the writer can judge, this particular group contains 497 which relate to originative invention, and 199 which relate to intensive invention, the proportion being approximately 5 to 2.

If the exploitation of intensive invention can occur with or without patents, while the full exploitation of originative invention is dependent upon patents, it would follow that where both classes of invention are being developed, the number of patents of proved utility to the holders might be less numerous in the former class than in the latter. That among such patents the number in the latter class appears actually to preponderate to such an extent as the figures above indicate is therefore entirely consistent with, and as far 
as it goes is even confirmatory of, the truth of this conclusion.

The excess of the sum of these two numbers over the total number of patents in the list, viz., 503, is accounted for by the fact that many of the inventions are for new or improved machines or appliances, and these are counted twice: firstly, the machine or appliance is itself reckoned as a new article; and secondly, the process or operation performed by the machine is reckoned as an improved process. Bearing in mind the difficulty in allocating the different inventions to the several classes, the originative inventions divide as follows: Machinery and appliances, 265 ; new or improved articles of manufacture, 183 ; new substances or materials, 49. In this grouping the first division includes only apparatus for facilitating the performance of industrial operations. An improved sewing machine for domestic use and a typewriter for office use are regarded as new articles. Telescopic sights for ordnance, means for opening and closing windows, coin-freed machines for automatic sale, are treated in the same way. One of the new articles is a paper-fastener. A great preponderance among the home in- 
ventions of those which relate to general engineering and building construction is also noticeable. These examples will serve to give some idea of the composition of the classes.

The addresses of the patentees show that of the 503 surviving patents those held by foreigners number 196.

The distribution of the foreign inventions is broadly similar to that of the home inventions, except that the proportion of new machines and appliances is rather greater, and of new substances or materials is almost double, the balance being made up by a deficiency of new articles.

The subject of foreign patents is further illustrated by the Table on p. 117, which shows the subjects and the distribution of the 196 foreign patents among the principal countries of origin.

Although the United States heads the list when the total numbers of patents obtained by foreigners in this country are compared, yet, if these totals are considered relatively to the numbers of patentees in each country, Germany stands by a long way first. In other words, German inventors and manu- 
United Kingdom Patents granted to Foreigners in 1894 which have sURvived the Full Term.

\begin{tabular}{|c|c|c|c|c|}
\hline Subject. & French & $\begin{array}{l}\text { Ger- } \\
\text { man. }\end{array}$ & $\begin{array}{l}\text { United } \\
\text { States. }\end{array}$ & Other. \\
\hline Chemical products $\ldots \quad \ldots$ & 8 & 25 & 1 & 3 \\
\hline Boot-making machinery ... & - & - & 13 & - \\
\hline Printing machinery ... ... & - & 3 & 12 & - \\
\hline Textile machinery ... & 3 & 5 & 8 & 3 \\
\hline Miscellaneous $\ldots \quad \ldots \quad \ldots$ & 17 & 30 & 47 & 18 \\
\hline Total $\ldots \ldots$ & 28 & 63 & 81 & 24 \\
\hline
\end{tabular}

facturers appear to have been much more active in securing patents of value and importance in this country than all others. It is also noteworthy that more than half the survivors among the patents granted for new substances or materials in this country in the selected year were obtained by Germans, while most of the others are held on the Continent. All the patents for boot-making machinery which have survived went to citizens of the United States. The United States also contributes a large group under the heading of printing machinery. The numbers under the heading of textile machinery are also given separately, as these refer to the 
largest of the export trades of the United Kingdom. The total under this heading very closely approaches the number, viz., 22, held by home patentees.

It should be remembered that the above figures and comparisons relate only to the 503 patents dating from a single year, and comprise only a relatively small fraction of the 65,000 to 70,000 existing patents. The analysis of so small a number does not enable any general conclusion to be drawn, and can only be regarded as illustrative. Different results might be obtained by taking another year. Thus it is curious that although during the past twenty years there has been a progressive advance in the weight and power of railway locomotives, this industry is not represented by a single surviving patent. The locomotive had become to a great extent standardised, as regards the main features of design, before 1894, and the subsequent improvement has been of the intensive kind. At the same time the motor-car industry, which has since attained to such large proportions, is equally unrepresented; the year 1894, which was too late for the locomotive, was too early for the motor-car. 


\section{CHAPTER VII}

PATENT Systems of ENGLAND, GERMANy, AND AMERICA COMPARED

$\prod \mathrm{HE}$ patent systems of different countries 1 diverge widely from each other; and, if their distinctive features are considered in the light of the preceding examination of the economic operation of patents, some of these differences will be seen to be of an economically fundamental character. Germany and the United States exhibit this divergence in the most extreme form. In both countries applications for patents are subjected to an examination as to novelty and patentability, but there the resemblance ceases. The United States system in its inception appears to be based mainly upon consideration for the individual inventor and his rights. For a single fee of $\& 7$ the inventor in the United States secures a patent for the full term of 
seventeen years, without any requirement as to working the invention, nor any liability in regard to the granting of licences. He may include in one patent all the matters, however numerous, which are required to form a complete machine, but must not include alternatives or modifications. Any combination of parts, if new, is regarded as an invention, independently of its being shown to possess any advantage over known combinations. Publication and use of the invention within a period of two years prior to the application is no bar to the grant of a patent to the true and first inventor. The German system, on the other hand, has regard mainly to economic advantage, and is designed to confine patent protection to the more important and real improvements, and to discourage the taking out of patents for mere innovations or variations in the form or execution of what is known generically. To this end, the applicant for a patent can secure the grant only on condition of showing that by his invention he attains some new technical advantage, and a combination, even if new, is not otherwise regarded as an invention. He may include several modifications 
ENGLAND, GERMANY, AND AMERICA 121

in one patent, but may not include improvements in parts which are not functionally interdependent. Prior publication in Germany in any form is a bar to the grant. Having obtained the grant, he is subject to stringent requirements in regard to manufacturing the invention in Germany, and is under the liability of having his patent revoked on failure to grant licences on reasonable terms. The period of the grant is fifteen years, and, beginning with the first year, progressively increasing annual fees are charged amounting in the aggregate for the full term to $£ 265$.

One more point may be cited to illustrate how divergent are the standpoints of the German and United States systems wherever divergence is possible. This is the form in which the "claim" is required to be expressed in the two countries. In Germany this must be in terms of the functions performed, and must not be merely an enumeration of component parts; while in the United States the claim must enumerate all the component parts of a working mechanism, and must not be defined merely in terms of functions.

It is not proposed to offer a complete account of the patent systems in these two 
countries; but a brief examination of those features which bear upon their economic action may illustrate the matters discussed in the preceding pages.

\section{Efficiency with regard to Originative Invention.}

It has been shown that the chief economic recommendation of the granting of patents is that patents do actually stimulate the general adoption of originative invention, and thereby tend to neutralise the inconveniences associated with the progress of intensive invention. The first question, then, in comparing two patent systems is: How does each affect originative invention? In this respect Germany and the United States would appear at first sight to be almost on a par, whatever advantage there may be on one side or the other apparently lying with the United States, in consequence of the longer period and cheapness of the United States patent and of its freedom from irksome conditions. It is probable, however, that the advantages attaching to the United States patent are so far counterbalanced by disadvantages of 
ENGLAND, GERMANY, AND AMERICA 123

another kind, that in the net result the German patent, in the case of originative invention, may afford a far more effectual protection, and therefore in the long run more effectual encouragement, to the inventor and manufacturer. The reasons for this conclusion are connected with the requirements of the law and of the Patent Offices in the two countries in respect to the form which the specification of the invention must take, and with the way in which the specification is construed in the determination of questions of infringement. Broadly, while in Germany generality in the specification is encouraged and interpretation is elastic, in the United States the Patent Office enforces certain restrictive conditions as to the form of the claims, and the courts of law construe the claims with the utmost rigidity.

In a patent for a mechanical invention in the United States, each claim must be for an "operative combination "- that is, for a complete working machine or appliance-and the parts may not be defined merely in terms of the functions they perform. The patentee, not being allowed to specify as the invention the new feature by itself, is compelled to sacri- 
fice generality by incorporating in the claim the rest of the machine or appliance. Combined with rigidity in interpretation, this exercises a seriously limitative effect upon his claim, and opens the way to considerable inroads upon the rights which the patent nominally confers. The following extract from "Notes on a Visit paid by Mr. F. J. S. Hopwood, C.B., C.M.G., in 1898, to the United States and Canadian Patent Offices" * illustrates these points:-

"Why do American patent experts draw so many claims for an invention?

"Answer.-This is largely due to the practice of the United States courts having jurisdiction on the patent cases in not permitting any distortion or flexibility of the particular language of the claims, the patentees being held down to the particular elements, and functions attributed to them, specified in each claim. Many American patent experts out of over-abundance of precaution cumber their patents with an undue number of claims. This practice has been repeatedly condemned in the United States courts."

* Report of Board of Trade Committee on Working of Patents Acts, 1901, First Appendix, par. 13. 
ENGLAND, GERMANY, AND AMERICA 125

"It is deemed necessary by many patent experts to draw numerous claims graduated in scope from the broadest to the narrowest, for the reason that in subsequent litigation legal bars may be discovered which will destroy the validity of the broader claims, and the patentee will thus still have the narrower claims of his patent to fall back upon. A multiplicity of claims is also regarded advisable by many for the purpose of completely covering and hedging in the invention, so that prospective infringers may be guarded against. It has been found in the past that whenever a valuable invention is patented in this country the patent is at once carefully studied in the interests of rival concerns with a view of devising means or of obtaining other patents to avoid the particular combination specified in such patent."

The difficulty experienced by the framers of American specifications in the attempt to protect an invention adequately is shown by the fact that it is not uncommon for upwards of a hundred separate claims to be set out for a single invention, each claim specifying a particular combination. Even so, the concluding statement in the extract given above 
suggests the practical impossibility of exhausting by these means all the combinations in which an invention may be utilised, and of forecasting all the ways in which a patent drawn on these lines and construed rigidly may be evaded. In this characteristic of the American system may perhaps be found the explanation of the fact that, as already mentioned, it has not been thought desirable in the United States to introduce any legal provision for the grant of compulsory licences. The main purpose of such provisions is to prevent a patentee from obstructing the introduction of improvements on his invention by refusing to allow the improver to use the foundation invention, without which in most cases the improvement cannot be employed; and their absence in a country where inventors are so prolific as in the United States may lead one to the inference that the way is open to the subsequent inventor to attain his ends without their aid. Similar considerations apply to the case of patents worked abroad but not in the United States.

Being subject to inroads of this kind, it is probable that originative invention is not so capable of full protection in America as in 
ENGLAND, GERMANY, AND AMERICA 127

Germany. In the latter country the claim is not only allowed to be expressed in general terms, but the inclusion in the specification of details as to the particular means employed in putting the invention into effect is discouraged. The specification is sufficient if it sets out clearly the nature of the means whereby the new technical effect is attained. Further, objection to the patent on the grounds of want of novelty or of patentability cannot be taken after the fifth year of the patent. Beyond this in the determination of questions of infringement the German law courts construe the patent liberally so as to give the inventor the protection to which he appears to be equitably entitled even though such protection may not fall strictly within the words and expressions in which the description and claims are couched. Lastly, the infringer is dealt with more severely in Germany, being liable not only in damages, as in England and in the United States, but also to fine and imprisonment.

Attitude towards Intensive Invention.

The second question in comparing the economic features of two patent systems is: 
What is their attitude towards intensive invention? In regard to this the inventor in the United States is in a distinctly more favourable position than the inventor in Germany. It does not follow, however, that the economic advantage lies on the same side. Reasons have been adduced for the belief that intensive invention develops almost equally well whether with or without patents; and not only does there not appear to be anything in the industrial development of Germany to suggest that this class of invention has been more backward there than elsewhere, but the vast strides made by German manufacturers prove the contrary. Yet in Germany nearly two out of every three applications for patent protection are rejected, which is nearly double the proportion of rejections in the United States. Considering the probably deterrent effect of the high proportion of rejections upon applicants, the relative stringency of the German as compared with the American system is even greater than is expressed by these figures alone. The German policy appears to regard multiplicity of patents as a hindrance to the free development of the industrial arts, and to aim at granting patents 
ENGLAND, GERMANY, AND AMERICA 129

only for completely novel inventions, or actual and undeniable improvements in existing inventions. This is the foundation for the German requirement that the attainment of some new technical effect is a necessary condition for securing the grant of a patent.

The refusal to grant separate patents for intensive inventions does not, however, necessarily throw them open to the world at large. The German system of construing liberally those relatively general specifications upon which patents are granted has been already alluded to. And under this system many minor variations and improvements which elsewhere might be regarded as independently patentable would naturally fall within the scope of some existing grant.

In the United States, on the other hand, not only is the criterion of originality less exacting, but the difficulties with which the framers of specifications have to contend in drafting broad patents operate, as already described, in favour of the subsequent improver who desires to avoid or to evade existing patents. Upon the whole it is safe to conclude that intensive invention in no 
manner lacks the protection of patents in America.

The advantage derived by the community from the publication of minor improvements which in the absence of patent facilities might be preserved as trade secrets has been referred to in connexion with English patents. It was then pointed out, however, that the \& average life of an English patent is five and a half years. When dealing with American patents it must be remembered that every patent is a grant for the full term of seventeen years.

In striking an economic balance between Germany and the United States on this question, we have on the one side greater freedom of manufacturers in regard to all those improvements which the German patent system ignores, coupled with the risk of greater general secretiveness in regard to such improvements; and on the other side greater inducements to publicity coupled with the risk of the manufacturer finding himself hampered by the multiplicity of unknown patents. No direct comparative valuation of these opposing considerations can be made; the working of the two systems can be judged only by results. 
ENGLAND, GERMANY, AND AMERICA 131

So far as the exports of manufactured goods is a test, reference to the Table on page 46 shows that the advantage appears to lie with Germany, both as regards the total values of the exports of manufactured goods and as regards the increase in annual value which took place between the years 1884 and 1904, in each of which Germany was ahead of the United States.

The patent system of this country occupies in regard to many of its features a middle position between those of Germany and of the United States. The total fee for the full term of fourteen years is rather less than half way between those of these two countries. In regard to what may be covered in one patent, the inventor in this country may include both alternative forms and the separate parts of a machine, subject to certain limitations in each case. There are no restrictions as to the form of the claim, and claims both in the American form and in the German form are common. A limited investigation as to novelty is made; but, provided the claim is at all distinguishable from what is found in previous patents, the 
patent is generally issued without any inquiry whether the alleged invention is in fact a real invention. This question is left to the determination of the law courts, by whom it has been laid down that if there is evidence of utility a very small amount of inventive ingenuity will suffice to support the patent. As regards the protection accorded to intensive invention, the English system is therefore akin to the American, subject to the important qualification previously mentioned, that on the average the life of an English patent is only a third of that of an American patent. On the other hand, in liberality of construction or interpretation of the claim the English system approaches the German, and therefore probably gives fuller protection and greater encouragement to originative invention than the American.

While the English system lies between the American and German systems in these respects, there is one very important matter in which it is equally distinguished from both. In the United States and in Germany the application is rejected if the alleged invention is not thought worthy of protection; and complaint is made that this practice leads to 
ENGLAND, GERMANY, AND AMERICA 133

many errors and anomalies which are highly injurious to the inventor. In this country patents can be refused only in very exceptional circumstances; but the applicant is required to be very explicit in the descriptive part of his specification, and in those cases where anticipations are found in the Patent Office he is called upon either to make clear the distinction upon which he relies or to submit to an indorsement of his specification with a reference to the anticipatory matter. In this way any one wishing to deal with, or affected by, the patent is made aware of the alleged anticipation, if the patentee attempts to ignore it, and is put in a position to judge for himself what may be the value of the patent in face of the prior publication. The object is to insure that while the patentee shall be prevented from imposing upon the public with a bogus patent, the inventor shall be protected from the consequences of an official mistake which, leading to the refusal of a patent, might do him an irremediable injury, and might result in the loss of a valuable invention to the industry to which the invention relates. This ingenious solution of a difficult problem, after being advocated in 
various influential quarters for about forty years, was brought into operation only in 1905. It is quite peculiar to the English system, and it has yet to be seen whether it will actually prove to secure all the advantages of an official investigation and at the same time avoid the disadvantages which have been complained of in the American and German systems.

\section{The Position of the Foreign Inventor.}

One of the most important questions concerning any patent system is: What inducements does it offer to inventors living abroad to take advantage of it? In this respect the English system has hitherto presented some remarkable features. In the year 1906, of the patents granted in this country 40 per cent. were granted to foreigners, while of those granted in Germany 34 per cent., and of those granted in the United States 10 per cent., were granted to foreigners. The corresponding percentages for this country in previous years, high as it was in 1906, were higher, having usually for many years been near 50 per cent. This percentage will generally be very high in countries where the 
manufacturing industries are in a backward state, for then most of the patents represent the enterprise of foreigners. That is manifestly not the explanation of the high percentage in this country. This way of stating the percentage is, however, liable to produce a misleading impression. In order to obtain comparative results, the patents granted to foreigners in each country should be calculated as a percentage of the inventors abroad, among whom, broadly speaking, the possible applicants for such patents are to be found. In the subjoined Table, the United Kingdom, Germany, and the United States are compared in this way.

Patents Granted to Foreigners in Three Princtpal Countries in 1906.

\begin{tabular}{|c|c|c|c|c|}
\hline & $\begin{array}{c}\text { A. } \\
\text { Patents } \\
\text { Granted } \\
\text { to } \\
\text { tationals. }\end{array}$ & $\begin{array}{c}\text { B. } \\
\text { Patents } \\
\text { Granted } \\
\text { to } \\
\text { Foreigners. }\end{array}$ & $\begin{array}{l}\text { C. Total } \\
\text { Patents } \\
\text { Granted, } \\
\text { Columed, } \\
\text { excluding } \\
\text { excose of } \\
\text { those of } \\
\text { each State } \\
\text { in turn. }\end{array}$ & $\begin{array}{l}\text { Ratio of } \\
\text { Numbers in } \\
\text { Colnum B } \\
\text { to those in } \\
\text { Columa C. }\end{array}$ \\
\hline $\left.\begin{array}{c}\text { United } \\
\text { Kingdom }\end{array}\right\}$ & 8,531 & 6,255 & 33,268 & $19 \cdot 4$ per cent. \\
\hline Germany & 6,290 & 3,310 & 35,509 & $9 \cdot 3$ \\
\hline $\left.\begin{array}{l}\text { United } \\
\text { States }\end{array}\right\}$ & 26,978 & 3,292 & 14,821 & $22 \cdot 2$ \\
\hline
\end{tabular}


Compared on this basis, the United States, of the three countries, appears to offer relatively the greatest attraction to the foreign inventor, England being not far behind. The low percentage of the patents issued in the United States obtained by foreigners is evidently due to the large numbers granted to the home inventor, which swamp those falling to the foreigner. The position of Germany in this Table is not, however, in any way due to unfavourable treatment of the foreigner in that country relatively to nationals. This is shown by the fact that during the years 1901-2-3, while German applicants obtained only 34 per cent. of the patents applied for, English applicants obtained 54 per cent. It is, in fact, due to the high standard of originality which the German Patent Office endeavours to maintain. Mention has been made of the proportion of rejections in the United States and in Germany: one out of three applications in the former and two out of three in the latter. If the proportion of rejections were the same in the two cases, the position of Germany in this Table would probably not differ greatly from that of the other two countries. Taking into account, 
ENGLAND, GERMANY, AND AMERICA 137

then, the differences in the patent systems of the three countries, any suspicion of differential treatment of the foreigner in one country or the other, or of his being unduly favoured in this country, that might suggest itself on a first inspection of the percentages, entirely disappears.

The use to which patents obtained by foreigners are put, however, stands on a different footing; and evidence exists that for many years patents held by foreigners have been employed to obstruct manufactures in this country to a considerable extent. This use of patents is guarded against in Germany by the enforcement of the requirement that the German demand shall, if possible, be supplied by German manufacture. Many cases are recorded of the annulment of patents in Germany on the ground of this requirement not having been satisfied. Similar provisions have recently been introduced into the English system, which came into operation in August, 1908. In the United States, although a change in the law has been advocated, no such requirement is at present made.

The way in which patents may be evaded, 
owing to the intricacies of the system on which American patent claims are drawn, has already been described in connexion with the subject of originative invention and its protection in the United States. It is possible that the obstructive use of patents held by foreigners is mitigated to some extent by these means, and it may be partly on this account that no provisions corresponding to the compulsory working clauses of other countries have as yet been introduced into the American law.

Comparative Values of Patent Grants in England and Germany.

The last point on which a comparison is offered is the relative pecuniary values to the holders of the patents granted under the different systems. Where patents in two countries are extinguished before the expiry of the full term by the exaction of payments for continuance, the rate of extinction relatively to the fees charged furnishes the means for deciding which series of patents is on the average the more valuable. In the United States there are no renewal fees, 
ENGLAND, GERMANY, AND AMERICA 139

but in Germany and the United Kingdom these data are available. The greater the rate of extinction for a given fee, the less the average value of the patents which lapse. Thus if, of a group of English patents subject to a renewal payment of $£ 10$, one-half are surrendered in preference to paying the fee, it is to be inferred that one-half are estimated to be worth less than $\& 10$ each and the other half worth more than $£ 10$ each. If the same payment causes the surrender of one-quarter of a similar group of German patents, three-quarters are seen to be thought worth more than $£ 10$ each and only onequarter of less value, and the average value of the latter series is clearly the greater. How much more it is impossible to estimate, since this portion of the series includes at one end of the scale those that are just on the border-line, and at the other end of the scale patents of immense value, such as that which the evidence in Gormully and Jeffrey's Petition showed to have brought to the holders a premium of $£ 70,000$ in consideration of the grant of an exclusive licence.

The following Table III. shows the superior value of the patents granted in Germany 
140 THE ENGLISH PATENT SYSTEM

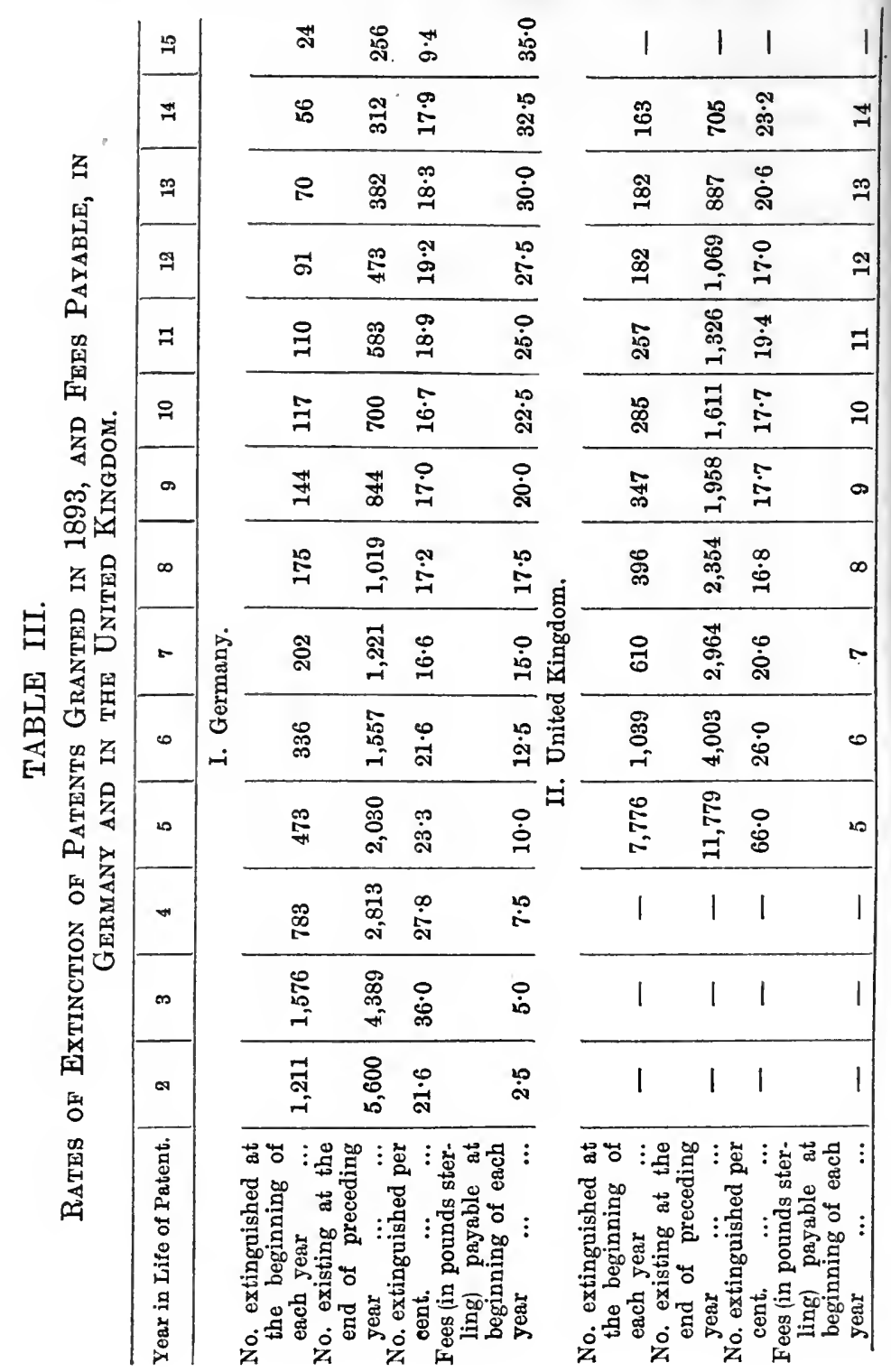


The total numbers of the patents granted in the two countries in the year 1893 which were extinguished by the renewal fees payable at the beginning of each year of the life of a patent are shown, together with the amounts of the fees. The year 1893 is chosen since, as a German patent lasts fifteen years, this is the latest year for which a full return is available.

It will be seen that the ratios of extinction of English patents are generally higher than those of German patents in corresponding years, notwithstanding that the English renewal fees range from one-half to only twofifths of those payable in Germany.

Another way of comparing the average values of the patents granted in England and Germany is to ascertain the numbers which survive equal fees. As the scales of fees are different in the two countries, this cannot be done directly; but curves may be drawn on a diagram, as shown below, and the intermediate values thereby approximately interpolated. The diagram refers only to the patents granted in 1893. The abscissæ of the marked points show the numbers of patents which survived the payment of the fees 
denoted by the ordinates of the points. It will be observed that the two curves cross at a point corresponding to about one thousand nine hundred patents, and a fee of $£ 8$. Below this point the numbers of patents which survive the same fee is greater in the United Kingdom than in Germany, while for

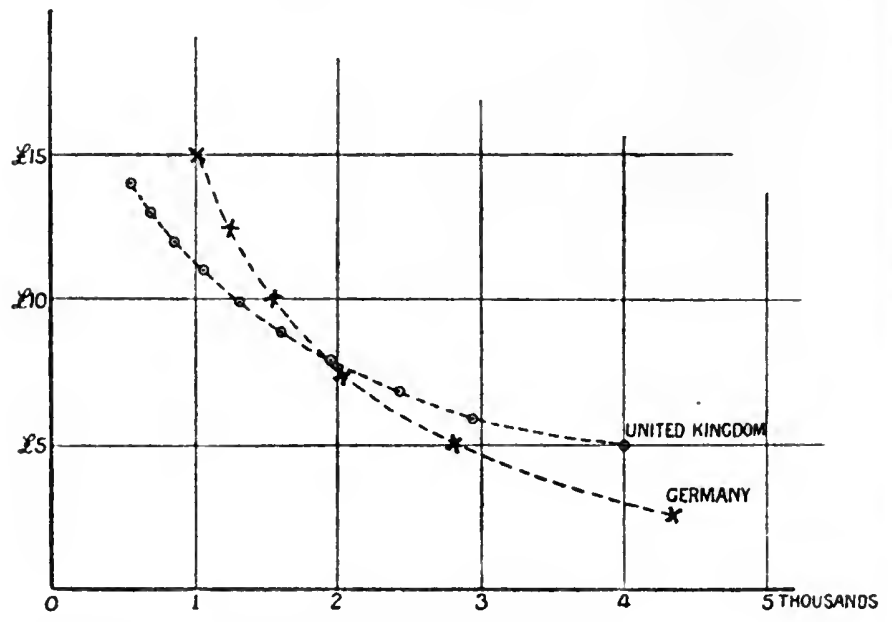

higher fees the reverse is the case. The common point refers to the commencement of the eighth year of the English patents and to an early period in the fourth year of the German patents.

The total number of patents granted in the United Kingdom in 1893 was very closely 
double the number granted in Germany. It might be expected that German patents would have a superior average value owing to the weeding out of the more worthless at an earlier stage by the official examination. If this were the chief or only explanation of the difference, it ought to be found that when, by the selective operation of the renewal fees, nineteen hundred patents in each group which survive the same fee have been segregated, their subsequent history as regards ability to pay fees ought to be the same. This result, however, is not realised, the vitality of the English patents being less than it should be on this supposition. Broadly, it would appear that the English eighth-year patent is about on a par with the German fourth-year patent, and that thereafter the German patent is the more valuable. It should be remembered in this connexion that objection on the ground of want of novelty or of patentability with a view to annulment can be taken to a German patent only within the first five years, while an English patent is open to these objections throughout its life. When with this is coupled the liberality in construction and 


\section{THE ENGLISH PATENT SYSTEM}

the other features of German Patent Law mentioned earlier in this section, there need be no difficulty in concluding that the superior value of the German patent during its later years is in all probability due to the more complete protection which it affords to the holder. 


\section{APPENDIX}

\section{PART I}

Extracts from the Statistical Abstracts issued by the Board of Trade relating to the Exports of certain Countries.

\section{NOTES.}

1. The columns headed "Manufactured Goods" do not include certain manufactures falling under the heading "Articles of Food." But the variations of these are not of such an amount as to affect materially the general conclusions drawn from the Tables as they stand.

2. In the case of Holland, a large quantity of goods which are free of import duty are entered as for Home consumption, although really in transit. Such goods when leaving the country reappear as exports of domestic produce. See Part II. of this Appendix in regard to this point.

3. In 1906 the United States classification was revised. In the Table below, the revision is carried back to 1897 , so that the entries from that date are not strictly comparable with those preceding it. 
HOLLAND.

\begin{tabular}{|c|c|c|c|}
\hline Year. & Total Value. & $\begin{array}{c}\text { Manufactured } \\
\text { Goods. }\end{array}$ & $\begin{array}{l}\text { Per Cent. } \\
\text { of Total. }\end{array}$ \\
\hline 1884 & $\begin{array}{c}\text { 1,000 gulden. } \\
841,232\end{array}$ & $\begin{array}{c}1,000 \text { gulden. } \\
228,614\end{array}$ & $27 \cdot 2$ \\
\hline 5 & 891,036 & 226,980 & $25 \cdot 5$ \\
\hline 6 & 949,489 & 206,189 & $21 \cdot 7$ \\
\hline 7 & 991,618 & 260,407 & $26 \cdot 3$ \\
\hline 8 & $1,114,806$ & 257,755 & $23 \cdot 1$ \\
\hline 9 & $1,094,079$ & 240,969 & $22 \cdot 0$ \\
\hline 1890 & $1,087,532$ & 268,009 & $24 \cdot 7$ \\
\hline 1 & $1,139,273$ & 241,093 & $21 \cdot 2$ \\
\hline 2 & $1,133,931$ & 283,573 & $25 \cdot 0$ \\
\hline 3 & $1,116,618$ & 247,436 & $22 \cdot 2$ \\
\hline 4 & $1,114,739$ & 243,156 & $21 \cdot 8$ \\
\hline 5 & $1,178,079$ & 253,170 & $21 \cdot 5$ \\
\hline 6 & $1,337,464$ & 267,654 & $20 \cdot 0$ \\
\hline 7 & $1,479,147$ & 281,719 & $19 \cdot 0$ \\
\hline 8 & $1,515,851$ & 306,048 & $20 \cdot 2$ \\
\hline 9 & $1,582,644$ & 295,891 & $18 \cdot 7$ \\
\hline 1900 & $1,695,251$ & 310,153 & $18 \cdot 3$ \\
\hline 1 & $1,733,686$ & 347,309 & $20 \cdot 0$ \\
\hline 2 & $1,827,903$ & 378,495 & $20 \cdot 7$ \\
\hline 3 & $1,950,958$ & 398,428 & $20 \cdot 4$ \\
\hline 4 & $1,985,587$ & 349,091 & $17 \cdot 6$ \\
\hline
\end{tabular}


APPENDIX

GERMANY.

\begin{tabular}{|c|c|c|c|}
\hline Year. & Total Value. & $\begin{array}{l}\text { Manufactured } \\
\text { Goods. }\end{array}$ & $\begin{array}{l}\text { Per Cent. } \\
\text { of Total. }\end{array}$ \\
\hline 1884 & $\begin{array}{c}1,000,000 \text { marks. } \\
3,205\end{array}$ & $\begin{array}{c}1,000,000 \text { marks. } \\
2,013\end{array}$ & $62 \cdot 8$ \\
\hline 5 & 2,860 & 1,800 & $62 \cdot 9$ \\
\hline 6 & 2,986 & 1,945 & $65 \cdot 1$ \\
\hline 7 & 3,135 & 2,049 & $65 \cdot 4$ \\
\hline 8 & 3,206 & 2,074 & $64 \cdot 7$ \\
\hline 9 & 3,167 & 2,099 & $66 \cdot 3$ \\
\hline 1890 & 3,328 & 2,147 & $64 \cdot 5$ \\
\hline 1 & 3,176 & 2,049 & $64 \cdot 5$ \\
\hline 2 & 2,955 & 1,950 & $66 \cdot 0$ \\
\hline 3 & 3,093 & 1,998 & $64 \cdot 6$ \\
\hline 4 & 2,963 & 1,879 & $63 \cdot 4$ \\
\hline 5 & 3,318 & 2,180 & $65 \cdot 7$ \\
\hline 6 & 3,525 & 2,301 & $65 \cdot 3$ \\
\hline 7 & 3,635 & 2,304 & $63 \cdot 4$ \\
\hline 8 & 3,757 & 2,396 & $63 \cdot 8$ \\
\hline 9 & 4,207 & 2,712 & 64.5 \\
\hline 1900 & 4,611 & 2,982 & $64 \cdot 7$ \\
\hline 1 & 4,431 & 2,892 & 653 \\
\hline 2 & 4,678 & 3,089 & $66 \cdot 0$ \\
\hline 3 & 5,015 & 3,281 & $65 \cdot 4$ \\
\hline 4 & 5,223 & 3,442 & $65 \cdot 9$ \\
\hline
\end{tabular}


FRANCE.

\begin{tabular}{|c|c|c|c|}
\hline Year. & Total Value. & $\begin{array}{l}\text { Manufactured } \\
\text { Goods. }\end{array}$ & $\begin{array}{l}\text { Per Cent. } \\
\text { of Total. }\end{array}$ \\
\hline 1884 & $\begin{array}{c}1,000 \text { francs. } \\
3,232,500\end{array}$ & $\begin{array}{c}1,000 \text { francs. } \\
1,690,000\end{array}$ & $52 \cdot 3$ \\
\hline 5 & $3,088,100$ & $1,630,900$ & $52 \cdot 8$ \\
\hline 6 & $3,248,800$ & $1,744,600$ & $53 \cdot 7$ \\
\hline 7 & $3,246,500$ & $1,738,500$ & $53 \cdot 5$ \\
\hline 8 & $3,246,700$ & $1,706,600$ & $52 \cdot 6$ \\
\hline 9 & $3,704,000$ & $1,925,900$ & $52 \cdot 0$ \\
\hline 1890 & $3,753,400$ & $1,999,000$ & $53 \cdot 3$ \\
\hline 1 & $3,569,700$ & $1,926,200$ & $53 \cdot 9$ \\
\hline 2 & $3,460,700$ & $1,878,800$ & $54 \cdot 3$ \\
\hline 3 & $3,236,400$ & $1,741,800$ & $53 \cdot 8$ \\
\hline 4 & $3,078,100$ & $1,657,200$ & $53 \cdot 9$ \\
\hline 5 & $3,373,800$ & $1,909,200$ & $56 \cdot 6$ \\
\hline 6 & $3,400,900$ & $1,912,900$ & $56 \cdot 2$ \\
\hline 7 & $3,598,000$ & $1,933,400$ & $53 \cdot 8$ \\
\hline 8 & $3,510,900$ & $1,915,800$ & $54 \cdot 6$ \\
\hline 9 & $4,152,600$ & $2,267,000$ & $54 \cdot 6$ \\
\hline 1900 & $4,108,700$ & $2,254,700$ & $54 \cdot 9$ \\
\hline 1 & $4,012,900$ & $2,249,400$ & $56 \cdot 0$ \\
\hline 2 & $4,252,200$ & $2,374,600$ & $55 \cdot 8$ \\
\hline 3 & $4,252,300$ & $2,413,500$ & $56 \cdot 8$ \\
\hline 4 & $4,451,000$ & $2,536,800$ & $57 \cdot 0$ \\
\hline
\end{tabular}




\section{SWITZERLAND.}

\begin{tabular}{|c|c|c|c|}
\hline Year. & Total Value. & $\begin{array}{l}\text { Manufactured } \\
\text { Goods. }\end{array}$ & $\begin{array}{l}\text { Per Cent } \\
\text { of Total. }\end{array}$ \\
\hline 1885 & $\begin{array}{c}1,000 \text { francs. } \\
669,740\end{array}$ & $\begin{array}{c}1,000 \text { francs. } \\
477,017\end{array}$ & $71 \cdot 2$ \\
\hline 6 & 669,011 & 484,899 & $72 \cdot 5$ \\
\hline 7 & 672,122 & 497,048 & $73 \cdot 9$ \\
\hline 8 & 673,672 & 496,038 & $73 \cdot 6$ \\
\hline 9 & 695,523 & 527,943 & $75 \cdot 9$ \\
\hline 1890 & 702,813 & 538,209 & $76 \cdot 6$ \\
\hline 1 & 671,867 & 511,434 & $76 \cdot 1$ \\
\hline 2 & 657,649 & 492,668 & 74.9 \\
\hline 3 & 646,451 & 485,530 & $75 \cdot 1$ \\
\hline 4 & 621,199 & 464,688 & $74 \cdot 8$ \\
\hline 5 & 663,360 & 503,287 & $75 \cdot 9$ \\
\hline 6 & 688,096 & 525,782 & 76.4 \\
\hline 7 & 693,173 & 529,107 & $76 \cdot 3$ \\
\hline 8 & 723,826 & 547,408 & $75 \cdot 6$ \\
\hline 9 & 796,014 & 616,252 & $77 \cdot 4$ \\
\hline 1900 & 836,080 & 643,895 & $77 \cdot 0$ \\
\hline 1 & 836,567 & 637,275 & $76 \cdot 2$ \\
\hline 2 & 874,305 & 657,932 & $75 \cdot 3$ \\
\hline 3 & 888,522 & 673,603 & $75 \cdot 8$ \\
\hline 4 & 891,479 & 673,406 & $75 \cdot 5$ \\
\hline
\end{tabular}


150 THE ENGLISH PATENT SYSTEM

ITALY.

\begin{tabular}{|c|c|c|c|c|c|}
\hline Year. & Total Value. & $\begin{array}{l}\text { Partly } \\
\text { Manufac- } \\
\text { tured } \\
\text { Goods. }\end{array}$ & $\begin{array}{c}\text { Per } \\
\text { Cent. of } \\
\text { Total. }\end{array}$ & $\begin{array}{l}\text { Manufac- } \\
\text { tured } \\
\text { Goods. }\end{array}$ & $\begin{array}{l}\text { Per } \\
\text { Cent. of } \\
\text { Total. }\end{array}$ \\
\hline 1884 & $\begin{array}{r}1,000 \text { lire. } \\
993,506\end{array}$ & $\begin{array}{l}1,000 \text { lire. } \\
289,579\end{array}$ & $29 \cdot 2$ & $\begin{array}{l}1,000 \text { lire. } \\
139,758\end{array}$ & $14 \cdot 1$ \\
\hline 5 & 917,914 & 291,084 & $31 \cdot 7$ & 148,820 & $15 \cdot 2$ \\
\hline 6 & 998,980 & 323,788 & $32 \cdot 4$ & 141,962 & $14 \cdot 2$ \\
\hline 7 & $1,031,484$ & 310,105 & $30 \cdot 1$ & 146,017 & $14 \cdot 1$ \\
\hline 8 & 949,837 & 348,067 & $36 \cdot 7$ & 133,473 & $14 \cdot 0$ \\
\hline 9 & 965,109 & 356,005 & $36 \cdot 9$ & 149,965 & $15 \cdot 5$ \\
\hline 1890 & 875,761 & 311,321 & $35 \cdot 5$ & 137,800 & $15 \cdot 8$ \\
\hline 1 & 876,800 & No & inform & ation & \\
\hline 2 & 958,187 & 361,437 & $37 \cdot 7$ & 131,132 & $13 \cdot 7$ \\
\hline 3 & 964,188 & 322,303 & $33 \cdot 4$ & 152,425 & $15 \cdot 8$ \\
\hline 4 & $1,032,799$ & 342,260 & $33 \cdot 1$ & 172,708 & $16 \cdot 7$ \\
\hline 5 & $1,037,708$ & 372,321 & $35 \cdot 9$ & 179,341 & $17 \cdot 3$ \\
\hline 6 & $1,052,098$ & 332,613 & $31 \cdot 6$ & 216,804 & $20 \cdot 6$ \\
\hline 7 & $1,091,734$ & 348,365 & $31 \cdot 9$ & 219,890 & $20 \cdot 2$ \\
\hline 8 & $1,203,569$ & 404,570 & $33 \cdot 6$ & 264,259 & $22 \cdot 0$ \\
\hline 9 & $1,431,416$ & 523,763 & $36 \cdot 6$ & 286,693 & $20 \cdot 0$ \\
\hline 1900 & $1,338,246$ & 449,728 & $33 \cdot 6$ & 303,376 & $22 \cdot 7$ \\
\hline 1 & $1,374,458$ & 505,322 & $36 \cdot 8$ & 311,428 & $22 \cdot 6$ \\
\hline 2 & $1,472,421$ & 558,071 & $37 \cdot 9$ & 309,568 & $21 \cdot 0$ \\
\hline 3 & $1,517,444$ & 534,657 & $35 \cdot 2$ & 323,310 & $21 \cdot 3$ \\
\hline 4 & $1,597,220$ & 551,699 & $34 \cdot 5$ & 408,482 & $25 \cdot 6$ \\
\hline
\end{tabular}




\section{UNITED STATES.}

\begin{tabular}{|c|c|c|c|c|c|}
\hline Year. & Total Value. & $\begin{array}{l}\text { Partly } \\
\text { Manufac- } \\
\text { tured } \\
\text { Goods. }\end{array}$ & $\begin{array}{l}\text { Per } \\
\text { Cent. of } \\
\text { Total. }\end{array}$ & $\begin{array}{c}\text { Manufac- } \\
\text { tured } \\
\text { Goods. }\end{array}$ & $\begin{array}{c}\text { Per } \\
\text { Cent. of } \\
\text { Total. }\end{array}$ \\
\hline 1884 & $\begin{array}{r}1,000 \text { dols. } \\
724,965\end{array}$ & 1,000 dols. & & $\begin{array}{c}1,000 \text { dols. } \\
136,373\end{array}$ & $18 \cdot 6$ \\
\hline 5 & 726,683 & & & 147,187 & $20 \cdot 2$ \\
\hline 6 & 665,965 & & & 136,542 & $20 \cdot 5$ \\
\hline 7 & 703,023 & & & 136,735 & $19 \cdot 5$ \\
\hline 8 & 683,862 & & & 130,300 & $19 \cdot 1$ \\
\hline 9 & 730,283 & \multicolumn{2}{|c|}{ See Note 3.} & 138,676 & $19 \cdot 0$ \\
\hline 1890 & 845,294 & & & 151,131 & $17 \cdot 9$ \\
\hline 1 & 872,270 & & & 168,927 & $19 \cdot 4$ \\
\hline 2 & $1,015,732$ & & & 158,511 & $15 \cdot 6$ \\
\hline 3 & 831,031 & & & 158,023 & $19 \cdot 0$ \\
\hline 4 & 869,205 & & & 183,718 & $21 \cdot 1$ \\
\hline 5 & 793,393 & & & 183,596 & $23 \cdot 2$ \\
\hline 6 & 863,200 & & & 228,571 & $26 \cdot 5$ \\
\hline 7 & $1,032,008$ & 98,284 & $9 \cdot 52$ & 212,959 & $20 \cdot 63$ \\
\hline 8 & $1,210,292$ & 101,991 & $8 \cdot 43$ & 222,537 & $18 \cdot 38$ \\
\hline 9 & $1,203,931$ & 117,730 & $9 \cdot 78$ & 262,657 & $21 \cdot 81$ \\
\hline 1900 & $1,370,764$ & 152,891 & $11 \cdot 15$ & 331,956 & $24 \cdot 15$ \\
\hline 1 & $1,460,463$ & 148,014 & $10 \cdot 12$ & 317,764 & $21 \cdot 76$ \\
\hline 2 & $1,355,482$ & 131,918 & $9 \cdot 73$ & 321,947 & $23 \cdot 75$ \\
\hline 3 & $1,392,231$ & 140,416 & $10 \cdot 09$ & 327,483 & $23 \cdot 52$ \\
\hline 4 & $1,435,179$ & 174,574 & $12 \cdot 17$ & 348,746 & $24 \cdot 30$ \\
\hline
\end{tabular}




\section{PART II.}

Correction of the Returns relating to Holland

in Respect to the Portion of the Transit Trade to and from Germany which is improperly entered as Domestic or "Special " Trade.

No exact correction can be made under this heading; but the considerations set out below show the way in which the percentages in the last column of the Table relating to Holland would probably be affected if the correction could be made. The conclusion arrived at is that, while all the percentages would be reduced, those in the later years would be reduced to a greater extent than those in the earlier years.

The correction would consist in a deduction to be made from the amounts entered in the second and third columns in the Table referred to. Whether goods, which are really in transit but are improperly returned as "special," are passing from Holland into Germany or from Germany into Holland, they finally appear in the Dutch returns as exports of domestic produce. The amount of the correction, therefore, would depend upon both the exports and the imports passing between Holland and Germany. In the absence of definite information, it is reasonable to assume in an illustrative calculation that the value of the goods improperly returned would be an approximately constant but unknown fraction of the values of these exports and imports added together. On this assumption, the deductions from the entries in the second column would be proportional to the sum of the total German exports and imports to and from Holland, and the 
deductions from the entries in the third column would be proportional to the sum of the corresponding exports and imports of manufactured goods. Only the totals are, however, given in the Statistical Abstracts; but here again it may be assumed that the proportion of manufactured goods is the same as that which obtains in the aggregate trade of Germany, and the required amounts can then be estimated as shown below:-

German Exports and Imports to ANd from aLL Countries.

\begin{tabular}{c|c|c|c}
\hline Year. & Total Value. & $\begin{array}{c}\text { Manufactured } \\
\text { Goods. }\end{array}$ & $\begin{array}{c}\text { Per cent. of } \\
\text { Total. }\end{array}$ \\
\hline & $\begin{array}{c}1,000,000 \text { marks. } \\
6,466\end{array}$ & $\begin{array}{c}1,000,000 \text { marks. } \\
2,930\end{array}$ & 45 \\
1884 & 11,587 & 4,662 & 40 \\
1904 & & & 40 \\
\hline
\end{tabular}

German Exports and Imports to and from Holland.

\begin{tabular}{c|c|c}
\hline Year. & Total Value. & \multicolumn{1}{|c}{$\begin{array}{c}\text { Manufactured Goods } \\
\text { (Estimated Value). }\end{array}$} \\
\hline & $\begin{array}{c}1,000 \text { gulden. } \\
708,994\end{array}$ & $\begin{array}{l}1,000 \text { gulden. } \\
319,000, \text { i.e., } 45 \text { per cent. of total } \\
1884\end{array}$ \\
1904 & $1,596,878$ & 638,751, i.e., 40 per cent. of total \\
\hline
\end{tabular}

On the assumptions specified, and taking round numbers, this last Table shows that the deductions from the entries relating to the year 1884 in the 
second and third columns in the Table of exports from Holland should be in the proportion 71:32. This would have the effect of reducing somewhat the percentage entered in the fourth column. In like manner, the deductions from the entries relating to the year 1904 should be in the proportion 160:64. The reduction of the percentage in this case would be greater than in the first case; since, in order to bring about an exactly equivalent reduction, the deductions should be in the proportion $160: 47$.

This result is evidently due to the fact that the trade in manufactured goods forms a larger and a more rapidly expanding part of the foreign trade of Germany than of Holland; and the deductions therefore chiefly affect the entries in the column devoted to manufactures, and more especially those referring to the later years. So long as these conditions hold, the qualification of the entries in the last column would be of the same nature, even although the special assumptions made above might be inaccurate. 


\section{APPENDIX}

\section{PART III.}

Summary relativg only to "Principal" Exports. HOLLAND.

\begin{tabular}{c|c|c|c}
\hline Year. & Total Value. & $\begin{array}{c}\text { Manufactured } \\
\text { Goods. }\end{array}$ & $\begin{array}{c}\text { Per Cent. } \\
\text { of Total. }\end{array}$ \\
\cline { 2 - 3 } 1861 & $\begin{array}{r}1,000 \text { gulden. } \\
203,339\end{array}$ & $\begin{array}{c}1,000 \text { gulden. } \\
27,262\end{array}$ & $13 \cdot 3$ \\
1873 & 356,902 & 97,834 & $27 \cdot 4$ \\
\hline
\end{tabular}

BELGIUM.

\begin{tabular}{c|c|c|c}
\hline Year. & Total Value. & $\begin{array}{c}\text { Manufactured } \\
\text { Goods. }\end{array}$ & $\begin{array}{c}\text { Per Cent. } \\
\text { of Total. }\end{array}$ \\
\hline 1884 & $\begin{array}{c}1,000 \text { francs. } \\
1,047,045\end{array}$ & $\begin{array}{c}1,000 \text { francs. } \\
431,103\end{array}$ & $41 \cdot 2$ \\
1905 & $1,347,961$ & 656,852 & $48 \cdot 7$ \\
\hline
\end{tabular}


if 


\section{INDEX}

Abolition of patents, Bismarck on, 102.

Abolition of patents in England, 10, 75 .

Abolition of patents in Holland, 9.

Agriculture and invention, 36 . to, 37 .

patents applicable

America, see United States.

Anti-industrial influences, 74.

Austria-Hungary, trade of, 44.

BelgiUM, trade of, 44, 49, 154. Birmingham hardware trade, 31.

Bismarck on patents, 102.

Blocking patents, 93.

Bluffing patents, 92 .

Board of Trade statistics, 42, 145.

Boot-making industry and patents, 89, 117.

Bottle-making machine, 53.

Buchanan on secret working, 107.

CaprTal protected by patents, 54.

Chamberlain's Patent Act, 88. Cheapening production, effect of, 23 .
Chemical industry and patents, 78, 93, 117.

Commerce and invention, 30. Competition, excessive, 29. Competitive character of intensive invention, 65, 68 .

Competitive improrements, $25,77$.

Compulsory licenses, 88, 126. $82,86,126,157$.

Conditions imposed by paten. tees, 89.

Curtis $v$. Platt, 59 .

Decline in proportion of British manufactured exports, 81 .

Depressed tradeand invention, 26.

EcoNoyst on abolition of patents, 75.

Electrical distribution of power, 65 . industry and patents, 93.

Employment affected by inrention, 22. and patents, 55 . Enterprise and inrention, 15. English export trade and patents, 81 . 
Examination of patent applications, official, 97, 133.

Exports, decline in proportion of British manufactured, 81. Exports of industrial nations compared, 41, 145.

Foreign holders of English patents, 80, 116.

" inventor, position of, in certain countries, 134.

$"$ trade and invention, $12,30$.

France, trade of, 41, 49, 148.

Free-trade and compulsory working, 85. in Holland, 35.

French holders of English patents, 117.

Fry's Commission, 96.

GARTON's system of plant breeding, 38.

"General over-production," $27,29$.

German holders of English patents, 117.

" patent system, 119.

" transit trade through Holland, 47, 152.

Germany, compulsory working in, 137.

$" \quad$ foreign patentees in, 80, 135.

$"$ infringement of patents in, 127.

$"$ value of patent grants in, 139. trade of, 41,49 ,
Grey, Sir Edward, on compulsory working, 34 .

HARDWARE trade, 31.

Holland, enterprise in, 50.

$" \quad$ trade of, $35,41,49$, 146, 154.

" industrial conditions in, $35,48$. in, 9.

Hopwood on American patents, 124.

IMPORTATION, 25, 77.

Improvements obstructed by patents, 76.

Industrial development and invention, 16.

Industries, localisation of, 31 . Infringement of patents in Germany, 127.

Intensive invention, 16, 58.

Intensive invention essentially competitive, $52,65,68$.

Intensive invention favoured in United States, 128.

Intensive invention independent of patents, 50, 114.

International trade and invention, 30.

Invalid patents a serious evil, 96.

Invention and unemployment, 22.

" apart from patents, 14.

36.

in agricultural arts,

Italy, trade of, $41,49,150$. 
LABOUR-SAVING machinery, 59, 63.

Lancashire textile industry, 31.

Levinstein on obstructive patents, 78, 94 .

Litigation, deterrent effect of uncertainty of, 95.

Lloyd George in justification of patents, 10.

Localisation of industries, 31 .

Long-lired patents, 112.

MACFIE on patents, 75 .

Machinery, industrial effects of, 59.

Mallock on directive ability, 15.

Manufacturer and patents, 54 , 77.

Manufacturing countries, trade of, $43,46,145$.

Martin on justification of patents, 11.

Mechanical handling of materials, 63.

Merit of inventor in relation to industry, 71 .

Mill on patents, 10.

Mischievous tendencies of patents, 74 .

Monopolies, see Patents.

Moulton, Lord Justice, on criterion of originality, 98.

Netherlands, see Holland above.

Non-working of patents, 76 .

Novelty of inventions, investi. gation of, 97.
Obstructive use of patents, 76.

Official investigation of patent applications, 97, 133.

Oppressive exercise of patent rights, 88.

Originative-intensive invention, 67, 70, 73 .

Originative invention, 16, 58.

Originative invention dependent on patents, 49, 114 .

Originative invention favoured in Germany, 123.

Originative invention not essentially competitive, 68 , 71.

Over-production, 27, 29.

"Patent," marking articles with word, 100.

" Office, action of Eng. lish, 97, 133.

" specifications, 92,96 , 142.

" system, inquiry into utility of, 12.

",$\quad$ justification of, 10.

" systems of certain countries compared, 119. Patents, abolition of, adrocated, 10, 75, 102.

, applicable to agriculture, 37. evidence of their operation, 34. in England largely held by foreigners, 80 . land, 9. 
Patents, number of, in force in England, 118.

" obstructive use of, 76.

" primary effect of, restated, 72.

Predaceous patents, 92.

Printing machinery, 99, 117.

Proctor $v$. Bennis, 59.

Protection and compulsory working, 85.

Publication of inventions, 108, 130.

Restraint of trade by invalid patents, 96.

Roberts on English agriculture, 39.

Russia, trade of, 44.

SECRET working of inventions, 107.

Shadwell on American bootmaking machinery, 89.

" on industrial change, 59.

" on steel trades, 31

Sheffield trades, 31.

Specifications of patents, 92, 96, 124.

Statute of monopolies, 36 .

Switzerland, trade of, 41, 49, 149.

Textile industry, 31, 117.

Times on abolition of patents, 75.

Trade, how affected by inventions, 12, 26.
Trade of industrial nations compared, 41, 145.

restrained by invalid patents, 96.

Transit trade through Holland, 47,152 .

UNEMPLOYMENT and patents, 55.

ventions, 22. affected by in-

United Kingdom, importance of inventions to, 33.

United Kingdom, trade of, 44, 49,481 .

United States, foreign patentees in, 80, 135.

United States holders of English patents, 117.

United States, patent system of, 119.

United States, trade of, 41 , $49,151$.

VAGUE patents, 92.

Vague patents simulated by marking machines "Patent," 100.

Values of patents in England and Germany, 139.

WaLlace and Williamson on secret-working, 111.

Wilson on English agriculture, 40.

ZrMmer on labour-saving machinery, 63. 




Please do not remove CARDS OR SLIPS FROM THIS POCKET

\section{UNIVERSITY OF TORONTO LIBRARY}


